This work is licensed under a Creative Commons Attribution License (CC BY 4.0).

\title{
On the diversity of subterranean beetles of the Dinarides: new leiodid taxa (Coleoptera: Leiodidae) from Serbia
}

\author{
Srećko ĆURČIĆ ${ }^{1, *}$, Dragan PAVIĆEVIĆ ${ }^{2,11}$, Nikola VESOVIĆ ${ }^{3}$, Maja VRBICA $^{4}$, \\ Miloš KURAICA ${ }^{5}$, Đorđe MARKOVIĆ ${ }^{6}$, Matija PETKOVIĆ ${ }^{7}$, Vladimir LAZOVIĆ ${ }^{8}$, \\ Dejan PANTELIĆ ${ }^{9} \&$ Fabrizio BOSCO ${ }^{10}$ \\ 1,3,4,5,7 Institute of Zoology, University of Belgrade - Faculty of Biology, \\ Studentski Trg 16, 11000 Belgrade, Serbia. \\ ${ }^{2}$ Serbian Biospeleological Society, Trg Dositeja Obradovića 2, 21000 Novi Sad, Serbia. \\ ${ }^{6}$ School of Zoology, George S. Wise Faculty of Life Sciences, Tel-Aviv University, \\ P.O. Box 39040, Tel Aviv 6997801, Israel. \\ ${ }^{8,9}$ Institute of Physics Belgrade, University of Belgrade, Pregrevica 118, 11080 Belgrade, Serbia. \\ ${ }^{10}$ A.F. Linder Association for the Study of Karst, Via Fratelli Cervi 9/G, \\ 34077 Ronchi dei Legionari, Italy. \\ ${ }^{11}$ Krunska 15, 11000 Belgrade, Serbia. \\ *Corresponding author: srecko@bio.bg.ac.rs \\ 2Email: dragan.pavicevic@hotmail.com \\ ${ }^{3}$ Email: nikola.vesovic@bio.bg.ac.rs \\ ${ }^{4}$ Email: maja.vrbica@bio.bg.ac.rs \\ Email: kuraica@gmail.com \\ ${ }^{6}$ Email: djordje.markovic@zoho.com \\ ${ }^{7}$ Email: matija.petkovic@bio.bg.ac.rs \\ ${ }^{8}$ Email: lazovicv@ipb.ac.rs \\ ${ }^{9}$ Email: pantelic@ipb.ac.rs \\ ${ }^{10}$ Email: fbosco1959@libero.it

\footnotetext{
${ }^{1}$ urn:Isid:zoobank.org:author:D495B4D6-C13B-4604-BA20-FB91AC31395A

${ }^{2}$ urn:lsid:zoobank.org:author:15893469-3368-4566-AF88-170CDF3DD072

${ }^{3}$ urn:1sid:zoobank.org:author:AA52F4F6-C952-4887-B257-FDBED464C5DA

${ }^{4}$ urn:1sid:zoobank.org:author:47E4BA55-887B-4BDB-A6BF-C8490ACE633A

${ }^{5}$ urn:lsid:zoobank.org:author:D08B8433-4F2B-4C1C-A741-6840F2B18B88

${ }^{6}$ urn:1sid:zoobank.org:author:8D3E0F6F-E182-480B-908C-373DC331E3EE

${ }^{7}$ urn:1sid:zoobank.org:author:EBAC2E4C-D69A-407B-9FE1-3587DA21628E

${ }^{8}$ urn:lsid:zoobank.org:author:DC9A3926-6CBF-41B9-9A25-3B5AED053BCA

${ }^{9}$ urn:Isid:zoobank.org:author:CE4DAE64-D33D-48CC-88CF-E6F35501B922

${ }^{10}$ urn:lsid:zoobank.org:author:918BD686-1CA3-45BA-8D22-A7C6FF81E4D3
}

\begin{abstract}
Three subterranean leptodirine leiodid taxa, viz., Bozidaria Ćurčić \& Pavićević gen. nov., Bozidaria serbooccidentalis Ćurčić \& Pavićević gen. et sp. nov. and Proleonhardella (Proleonhardella) tarensis Ćurčić \& Pavićević sp. nov., are described and diagnosed. Bozidaria Ćurčić \& Pavićević
\end{abstract}


gen. nov. belongs to the phyletic series of "Leonhardella". The new beetle taxa differ from their closest relatives in numerous morphological characters. They most likely belong to phyletic lineages of Pliocene age. The new leiodid taxa are endemic to the Dinaric mountain chain of western Serbia. Keys to the leptodirine leiodid genera of the phyletic series of "Leonhardella" and to the taxa of the genus Proleonhardella Jeannel, 1910 are included.

Keywords. New genus, new species, endogean and cave-dwelling, Cholevinae, Leptodirini.

Ćurčić S., Pavićević D., Vesović N., Vrbica M., Kuraica M., Marković Đ, Petković M., Lazović V., Pantelić D. \& Bosco F. 2021. On the diversity of subterranean beetles of the Dinarides: new leiodid taxa (Coleoptera: Leiodidae) from Serbia. European Journal of Taxonomy 782: 55-81. https://doi.org/10.5852/ejt.2021.782.1589

\section{Introduction}

A moderately rich endogean and a relatively poor cave-dwelling fauna of leiodid beetles occur in Serbia. This diversity is highest in the western and southwestern parts of the country (Jeannel 1924; Perreau 2000; Ćurčić 2005; Ćurčić et al. 2006, 2008b, 2015, 2018). Most subterranean leptodirine taxa from Serbia are either bathyscioid (Magdelainella spp., Proleonhardella spp., Pavicevicia spp., Bathyscia montana apfelbecki Ganglbauer, 1899 and Pseudobathyscidius serbicus (Karaman, 1964)) or pholeuonoid (Pholeuonopsis spp.) (Jeannel 1924; Nonveiller 1983; Moldovan et al. 2018; Perreau 2019). Highly-evolved scaphoid taxa are the representatives of the genus Remyella Jeannel, 1931, which are distributed in a narrow Dinaric area in southwestern Serbia and northeastern Montenegro (Njunjić et al. 2017). Interestingly, no highly-evolved leptodiroid taxa are known from Serbia so far, although some species of Anthroherpon Reitter, 1889 inhabit certain areas close to the country's border (Njunjić et al. 2015). Most leiodid taxa from Serbia are associated with the Central Dinarides, a smaller amount with the Inner Dinarides, while the Carpathian-Balkan mountain system is characterized by only a few taxa (e.g., the endemic genus Pseudobathyscidius Karaman, 1964 and the endemic Magdelainella subgenus Derveniella Pavićević \& Perreau, 2008) (Perreau 2015; Hlaváč et al. 2017).

The genus Proleonhardella Jeannel, 1910 currently includes 10 endemic taxa (eight species and two subspecies) (Perreau 2000, 2015; Hlaváč et al. 2017), which were all described in the first half of the twentieth century. Proleonhardella taxa are distributed in a narrow Dinaric area belonging to Bosnia and Herzegovina, Serbia, and Montenegro (Perreau 2000; Pavićević et al. 2012). The genus is divided into two subgenera: Proleonhardella Jeannel, 1910 and Pholeuonillus Breit, 1913. The former subgenus includes seven species and two subspecies inhabiting caves in the montane areas of central, eastern and southeastern Bosnia and Herzegovina, southwestern Serbia and northern Montenegro (Perreau 2000; Pavićević et al. 2012). The latter subgenus contains only one endogean montane species from southern Bosnia and Herzegovina (Perreau 2000). Two species of Proleonhardella occur in Serbia: Proleonhardella (Proleonhardella) hirtella Jeannel, 1934 (described from the Popova Pećina Cave, village of Seljane, near the town of Prijepolje, southwestern Serbia) and P. (P.) remyi Jeannel, 1934 (described from the Bjeloševačka (= Dvostruka) Pećina Cave, village of Bjeloševina, near the town of Pljevlja, northern Montenegro) (Fig. 9) (Perreau 2000).

In the chapter on the family Leiodidae in the recent Catalogue of Palaearctic Coleoptera, Perreau (2015) reported the presence of both species of Proleonhardella solely for Serbia (Pešter Plateau). In reality, the type localities of both species are not situated on the Pešter Plateau, but in its surroundings. Additionally, they inhabit the territory of Montenegro, as documented by Pavićević et al. (2012) and Hlaváč et al. (2017). Namely, P. (P.) hirtella, besides its type locality, is known to inhabit three caves and pits near the towns of Prijepolje and Priboj (southwestern Serbia) and one pit near the town of Pljevlja (northern 
Montenegro) (Pavićević et al. 2012). On the other hand, P. (P.) remyi, besides its type locality, lives in numerous caves and pits in the area of Kamena Gora and near the towns of Prijepolje and Priboj (southwestern Serbia), as well as in two caves and one pit near the town of Pljevlja (northern Montenegro) (Pavićević et al. 2012). The two species cohabitate in some caves and pits (five such localities are known), where the populations of the latter are more abundant (Pavićević et al. 2012). Additionally, the type locality of $P$. (P.) remyi in northern Montenegro is erroneously reported by Perreau (2000) to be situated in Serbia.

On the basis of the current distribution of Serbian endogean and cave-dwelling leiodid taxa, we assumed that some taxa new to science (genera and species) might be discovered in certain karstic areas of the Dinaric Alps of Serbia, which were so far not investigated and from which no taxa of leiodids from the underground have been documented.

Several field surveys conducted by the staff of the Institute of Zoology, University of Belgrade Faculty of Biology and the Institute for Nature Conservation of Serbia at a few speleological sites in western Serbia, as well as by the late Prof. Guido Nonveiller on Mt Bobija in western Serbia, resulted in the discovery of a new leptodirine genus, viz., Bozidaria Ćurčić \& Pavićević gen. nov., and two new leptodirine species, $B$. serbooccidentalis Ćurčić \& Pavićević gen. et sp. nov. and Proleonhardella (Proleonhardella) tarensis Ćurčić \& Pavićević sp. nov., the descriptions and diagnoses of which are given in the current study.

\section{Material and methods}

The material of Bozidaria serbooccidentalis gen. et sp. nov. is comprised of a large series of individuals: four males and five females collected in traps for endogean fauna baited with rotten meat during 1980 on Mt Bobija, near the town of Ljubovija, western Serbia, as well as 30 males and 44 females collected by pitfall trapping during 2010 and 2017 in the Simina Jama Pit, village of Gornje Košlje, Debelo Brdo saddle, Mt Povlen, near the town of Ljubovija, western Serbia. That of Proleonhardella (Proleonhardella) tarensis sp. nov. includes four males and four females collected by pitfall trapping during 2014 in Pit 4-1-3-27, village of Kaluđerske Bare, Mt Tara, near the town of Bajina Bašta, western Serbia, as well as three males and five females collected by pitfall trapping during 2003 in the Sovljačka Pećina Cave, village of Šljivovica, Mt Tara, near the town of Bajina Bašta, western Serbia.

Type specimens were studied in the laboratories of the Institute of Zoology, University of Belgrade Faculty of Biology, Belgrade, Serbia. The beetles were dissected, analysed in detail and photographed. Dry individuals were glued onto rectangular paper mounting cards. Extracted genitalia were fixed in a medium composed of Canada balsam and toluene and put onto rectangular transparent plastic mounting cards placed on the same entomological pin together with the mounting card of the dry individual.

Observations were conducted with a Carl Zeiss-Stemi 2000 binocular stereo microscope. A Nikon SMZ 18 stereo microscope combined with a Nikon DS-Filc digital camera, as well as a Leica DMLS light microscope combined with a Leica DC 300 camera, were used to photograph morphological details of the whole specimens and genitalia of new beetle taxa. The detailed morphology of the new taxa was imaged using scanning electron microscopy (SEM) at the Photonics Center, Institute of Physics Belgrade, University of Belgrade. SEM micrographs were made using a MIRA3 FEGSEM field-emission scanning electron microscope (FESEM) (Tescan, Brno, Czech Republic) in high vacuum mode, at a voltage of $15 \mathrm{kV}$. All samples were sputter coated with gold/palladium for 30 seconds. The index of intensity of the electron beam was 15.00. Pressure in the column was about $127 \mathrm{MPa}$. 


\section{Abbreviations of measurements}

$\mathrm{A} 1 / \mathrm{A} 2=$ ratio of length of antennomere I to length of antennomere II

$\mathrm{A} 3 / \mathrm{A} 2=$ ratio of length of antennomere III to length of antennomere II

$\mathrm{A} 3 / \mathrm{A} 5=$ ratio of length of antennomere III to length of antennomere $\mathrm{V}$

A7/A6 $=$ ratio of length of antennomere VII to length of antennomere VI

A7/A8 $=$ ratio of length of antennomere VII to length of antennomere VIII

A8LW $=$ ratio of length to width of antennomere VIII

A9LW $=$ ratio of length to width of antennomere IX

A9/A8 $=$ ratio of length of antennomere IX to length of antennomere VIII

A10LW $=$ ratio of length to width of antennomere $\mathrm{X}$

$\mathrm{A} 11 \mathrm{LW}=$ ratio of length to width of antennomere XI

$\mathrm{A} 11 / \mathrm{A} 9+\mathrm{A} 10=$ ratio of length of antennomere XI to length of antennomeres IX and X combined

$\mathrm{EL} / \mathrm{EW} \quad=$ ratio of length of elytra (as linear distance between base to apex of elytra along median suture) to maximum width of elytra

$\mathrm{EL} / \mathrm{PL} \quad=$ ratio of length of elytra (as linear distance between base to apex of elytra along median suture) to length of pronotum

$\mathrm{HL} / \mathrm{HW}=$ ratio of length of head (as linear distance between anterior margin of clypeus to occipital carina) to maximum width of head

$\mathrm{M} \quad=$ mean value for certain measurements

$\mathrm{P} 1 \mathrm{LW}=$ ratio of length to width of protarsomere I

$\mathrm{PB} / \mathrm{AM} \quad=$ ratio of length of pronotal base to length of anterior pronotal margin

$\mathrm{PL} / \mathrm{PW} \quad=$ ratio of length of pronotum to maximum width of pronotum

$\mathrm{PL}+\mathrm{EL} / \mathrm{AL}=$ ratio of length of pronotum and elytra combined (as linear distance between anterior pronotal margin to apex of elytra along median suture) to total antennal length

$\mathrm{R}=$ range of measured values

$\mathrm{TL}=$ maximum body length from anterior margin of clypeus to apex of elytra along median suture

\section{Repositories}

$\mathrm{CDP}=$ collection of Dragan Pavićević, Belgrade, Serbia

IZFB = Institute of Zoology, University of Belgrade - Faculty of Biology, Belgrade, Serbia

SBS $=$ Serbian Biospeleological Society, Novi Sad, Serbia

Other abbreviations used in the text

$\mathrm{Ma}=$ million years

Mt $=$ Mountain/Mount

\section{Other material examined}

Proleonhardella (Proleonhardella) hirtella Jeannel, 1934

SERBIA 1 đ̃; southwestern Serbia, municipality of Priboj, village of Krnjača, Tmuša Gorge, Goveđa Pećina Cave; 17 Jul. 2013; Dragan Antić leg.; IZFB.

Proleonhardella (Proleonhardella) remyi Jeannel, 1934

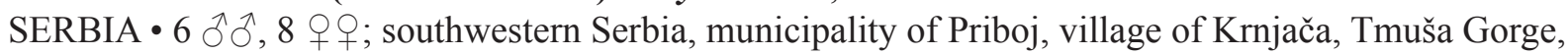

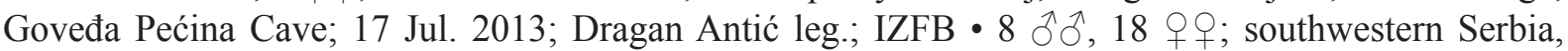
municipality of Prijepolje, Kamena Gora, village of Kamena Gora, Bezdan Pit; 20 May-5 Nov. 2017; Miloš Kuraica leg.; pitfall traps; IZFB. 


\title{
Results
}

\author{
Subphylum Hexapoda Latreille, 1825 \\ Class Insecta Linnaeus, 1758 \\ Order Coleoptera Linnaeus, 1758 \\ Suborder Polyphaga Emery, 1886 \\ Family Leiodidae Fleming, 1821 \\ Subfamily Cholevinae Kirby, 1837 \\ Tribe Leptodirini Lacordaire, 1854
}

Genus Bozidaria Ćurčić \& Pavićević gen. nov.

urn:1sid:zoobank.org:act:8CF69930-741E-4484-9F09-5E8C1FBC86AA

\section{Type species}

Bozidaria serbooccidentalis Ćurčić \& Pavićević gen. et sp. nov., by monotypy.

\section{Diagnosis}

Bozidaria gen. nov. is most closely related to the following Dinaric genera of the group Théléomorphes belonging to the phyletic series of "Leonhardella" (Jeannel 1924): Proleonhardella, Blattochaeta Reitter, 1910, Augustia Zariquiey, 1927 and Pholeuodromus Breit, 1913. These genera share a similar body form, the presence of tetramerous tarsi in males, the absence of a comb on anterior tibiae, the first antennomere clearly shorter than the second antennomere, apically widened distal antennomeres, the absence of sutural striae, and the presence of a similar type of aedeagus.

The new genus differs from its closest relatives in the body shape (elliptical, elongate vs bathyscioid, oval/ovoid, mostly wide in Proleonhardella), TL (R 2.51-2.80 $\mathrm{mm}$ vs R 4.0-5.5 $\mathrm{mm}$ in Blattochaeta and R 3.8-4.6 mm in Pholeuodromus), body pubescence (short, recumbent vs long, erect in Blattochaeta), shape of antennae (elongate, thin, including distal antennomeres vs short, distal antennomeres wide, barely longer than wide in Proleonhardella), length of antennae (exceeding the middle of the body vs reaching, but not exceeding the middle of the body in Augustia and not reaching the middle of the body in Pholeuodromus), presence/absence of mesosternal carina (present vs absent in Augustia), shape of mesosternal carina (with no concavity on its anterior border, not atrophied vs with a concavity on its anterior border in Blattochaeta and atrophied posteriorly in Pholeuodromus), shape of lateral pronotal margins (arcuate vs weakly convex in Augustia), position of maximum pronotal length (sub-basally vs at base in Pholeuodromus), ratio of pronotum width to elytral width (pronotum slightly narrower than elytra vs pronotum as wide as elytra in Blattochaeta and Pholeuodromus and pronotum clearly narrower than elytra in Augustia), shape of elytra (more rounded, gradually narrowed distally vs less rounded, more pronouncedly attenuated distally in Augustia), shape of aedeagus (long, elongate vs short, wide in Blattochaeta and Augustia and mostly wide in Proleonhardella), shape of basal bulb (elongate, narrow vs short, rounded in Proleonhardella, Blattochaeta and Augustia) and its basal projection (long vs short in Proleonhardella and Augustia), and shape of parameral apex (narrow vs widened in Blattochaeta) (Jeannel 1910, 1924, 1930, 1931, 1934; Reitter 1910; Breit 1913; Zariquiey 1927; Knirsch 1928; Guéorguiev 1976).

\section{Etymology}

This genus is named after the late Academician Božidar Ćurčić, a well-known Serbian biospeleologist and zoologist. 


\section{Description}

Habitus. A small-sized elliptical leptodirine with short and wide head, transverse pronotum and elongate obovoid elytra. Blind, reddish-brown, body shiny, densely pubescent, dorsoventrally convex, finely punctate. Pubescence composed of short yellow hairs, on pronotum and elytra recumbent, while on head erect. Legs and antennae long and slender, densely pubescent. Microsculpture composed of isodiametric meshes.

HEAD. Anophthalmous, of almost equal length and width. Antennae inserted medially on head, elongate, thin, apically widened and flattened, exceeding middle of body, reaching basal third of elytral length. Antennomere I shorter than antennomere II. Antennomere III shorter than antennomere II and longer than antennomere IV. Antennomeres IV-VI of similar length. Antennomere VII elongate, apically widened. Antennomere VIII short, elongate, oval. Ultimate antennomere slender, ovoid, about as long as antennomeres IX and X combined. Occipital carina present.

THorax. Pronotum almost twice as wide as long, with arcuate and well-rounded lateral margins, slightly narrower than elytra, widest slightly prior to pronotal base. Mesosternal carina well-developed, with no furrow, high, obtuse-angled, with an apical tooth.

Elytra. Elongate, much longer than pronotum, rounded medially, regularly arcuate distally, not attenuated. Scutellar striae absent. A part of pygidium not covered by elytra.

LeGs. Extended and slender. Fore tarsi tetramerous. Male protarsi dilated. Tibiae with spines on external edges. No comb on external edges or apical parts of protibiae. Meso- and metatibiae with no apical baskets.

AвDOMEn. Median lobe of aedeagus slender, rounded sub-terminally, with an elongate triangular apex. Basal bulb elongate, narrow, with a long sub-triangular basal projection. Each paramere longer than median lobe, thin, sub-terminally widened, with three apical setae.

GoNOSTYLI. Elongate, slender, almost straight.

\section{Distribution}

The new genus is currently known to inhabit deep soil on Mt Bobija and the Simina Jama Pit on Mt Povlen in the surroundings of the town of Ljubovija, western Serbia. It is probable that it might be present both in the soil and caves of the adjacent areas.

\section{Key to the leptodirine leiodid genera of the phyletic series of "Leonhardella"} (modified after Guéorguiev 1976) (Fig. 1)

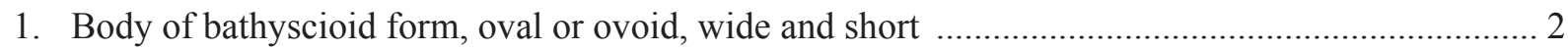

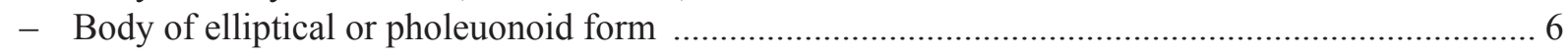

2. Mesosternal carina absent (Fig. 1A). Cavernicolous, Mt Čvrsnica, southwestern Bosnia and Herzegovina Augustia Zariquiey, 1927

- Mesosternal carina present (Fig. 1B) ....................................................................................... 3

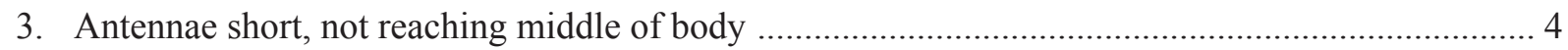

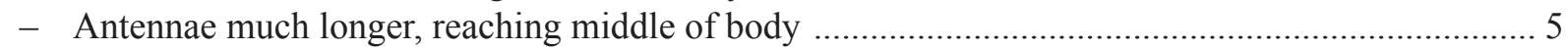

4. Pubescence fine and recumbent, except in both lateral exterior border of elytra and apical elytral half, where long hairs occur. Antennae very short, barely exceeding pronotal base. Longer species 
(TL $2.5 \mathrm{~mm}$ ). Mesosternal carina rounded. Basal lamina of tegmen of aedeagus without tooth. Cavernicolous, region of Kuči, vicinity of the city of Podgorica, eastern Montenegro

Weiratheria Zariquiey, 1927

- Pubescence entirely normal and recumbent. Antennae somewhat longer, but not reaching middle of body. Shorter species (TL $1.85 \mathrm{~mm}$ ). Mesosternal carina triangular. Basal lamina of tegmen of aedeagus with a pronounced tooth basally. Cavernicolous, vicinity of the town of Karystos, island of Euboea, southern Greece

Henrotiella Perreau, 1999

5. Pubescence short and recumbent. Anterior border of mesosternal carina without concavity (Fig. 1C). Protarsi weakly dilated in males. Shorter species (TL 1.3-3.5 mm). Cavernicolous and endogean, central, eastern and southern Bosnia and Herzegovina, southwestern and western Serbia and eastern Montenegro

Proleonhardella Jeannel, 1910

- Pubescence long and erect. Anterior border of mesosternal carina with a deep concavity (Fig. 1D). Protarsi not dilated in males. Longer species (TL 4.0-5.5 mm). Cavernicolous, western, southwestern and eastern Montenegro, southern Bosnia and Herzegovina and southern Croatia

Blattochaeta Reitter, 1910

6. Body of elliptical form (Fig. 1E). Pronotum regularly or almost regularly arcuate, slightly narrower than elytra or as wide as elytra

- Body of pholeuonoid form (Fig. 1F). Pronotum campanuliform or strongly sinuated backwards, clearly narrower than elytra

7. Body shorter (TL 1.8-2.0 mm). Antennae almost reaching middle of body. Elytra very attenuated apically, with sparse pubescence. Ventral border of mesosternal carina triangular and deeply grooved. Endogean and cavernicolous, southern Croatia and western Bosnia and Herzegovina

Anisoscapha Müller, 1917

- Body longer (TL 2.5-5.2 mm). Antennae reaching middle of body. Elytra regularly arcuate apically, with dense pubescence. Ventral border of mesosternal carina not grooved

8. Body shorter (TL 2.5-3.0 mm). Mesosternal carina not atrophied. Protarsi dilated in males (Fig. 1G)

- Body longer (TL 3.8-5.2 mm). Mesosternal carina atrophied posteriorly. Protarsi not dilated in males (Fig. 1H)

9. Body very elongate and narrower. Pubescence long and erect. Median lobe more elongate, thin. Basal bulb small, with a short rounded basal projection (Fig. 1I). Paramerae distally widened. Cavernicolous, southern and southeastern Bosnia and Herzegovina and western Montenegro .....

Anillocharis Reitter, 1903

- Body less elongate and wider. Pubescence short and recumbent. Median lobe less elongate, wide. Basal bulb elongate, with a long sub-triangular basal projection (Fig. 1J). Paramerae distally narrow. Endogean and cavernicolous, Mts Bobija and Povlen, western Serbia

Bozidaria Ćurčić \& Pavićević gen. nov.

10. Body shorter (TL 3.8-4.6 mm). Pronotum as wide as elytra. Lateral pronotal margins regularly arcuate. Anterior border of mesosternal carina with no concavity. Paramerae with three setae. Endogean, central and southern Bosnia and Herzegovina

Pholeuodromus Breit, 1913

- Body longer (TL 5.0-5.2 mm). Pronotum slightly narrower than elytra. Lateral pronotal margins weakly sinuate in basal third. Anterior border of mesosternal carina with a deep concavity. Paramerae with four setae. Cavernicolous, southeastern Bosnia and Herzegovina and northern Montenegro ... 

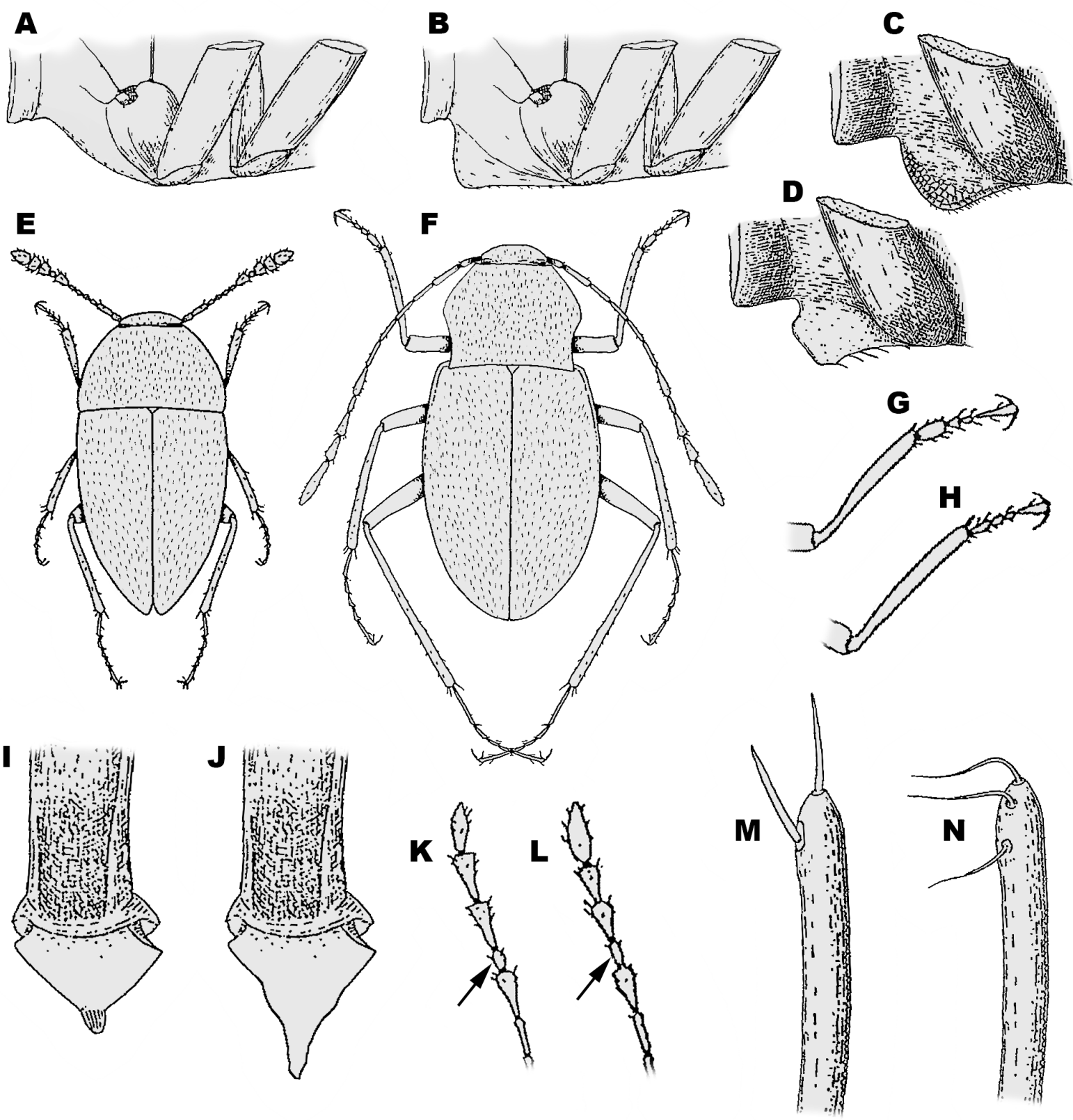

Fig. 1. Illustrations of morphological characters presented in the Key to the leptodirine leiodid genera of the phyletic series of "Leonhardella" (after Jeannel 1911, 1924; Ćurčić et al. 2008a). A. Absence of mesosternal carina. B. Presence of mesosternal carina. C. Absence of a concavity on mesosternal carina. D. Presence of a deep concavity on mesosternal carina. E. Presence of elliptical body shape. F. Presence of pholeuonoid body shape. G. Presence of dilated protarsi in males. H. Presence of undilated protarsi in males. I. Presence of a short rounded basal projection on basal bulbus. J. Presence of a long subtriangular basal projection on basal bulbus. K. Presence of subglobular antennomere VIII. L. Presence of elongate antennomere VIII. M. Presence of paramerae with two setae. N. Presence of paramerae with three setae. 
11. Antennomere VIII subglobular (Fig. 1K). Elytral punctuation strong and deep. Pubescence long, usually double, with bristle-like setae. Cavernicolous and endogean, western Serbia, southern, southeastern, central, western and eastern Bosnia and Herzegovina and northwestern Montenegro

Pholeuonopsis Apfelbeck, 1901

- Antennomere VIII elongate (Fig. 1L). Elytral punctuation fine and shallow. Pubescence short, with no bristle-like setae

12. Body shorter (TL $2.0 \mathrm{~mm}$ ). Pronotum elongate, very narrow basally. Mesosternal carina low. Paramerae with two setae (Fig. 1M). Cavernicolous, vicinity of the town of Ključ, western Bosnia and Herzegovina

Deelemaniella Perreau, 2002

- Body longer (TL 3.2-4.5 mm). Pronotum as long as wide or transverse, wider basally. Mesosternal carina high or atrophied. Paramerae with three setae (Fig. 1N)

13. Mesosternal carina high. Protarsi somewhat dilated in males. Tibiae with no external spur. Cavernicolous, northwestern, western and northern Montenegro and southeastern and southern Bosnia and Herzegovina Leonhardella Reitter, 1903

- Mesosternal carina atrophied. Protarsi not dilated in males. Tibiae with external spur. Cavernicolous, Mt Durmitor, northern Montenegro Tartariella Nonveiller \& Pavićević, 1999

Bozidaria serbooccidentalis Ćurčić \& Pavićević gen. et sp. nov. urn:1sid:zoobank.org:act:A2B51421-4CD9-4696-BF46-7EACBC395C4E

Figs 2-3

\section{Diagnosis}

The genus is currently monotypic and therefore a differential diagnosis for Bozidaria serbooccidentalis gen. et sp. nov. cannot be provided.

\section{Etymology}

The species is named after western Serbia, where its type locality and known localities are situated.

\section{Type material}

\section{Holotype}

SERBIA • ${ }^{\lambda}$; western Serbia, town of Ljubovija, Mt Bobija; alt. 1000 m; 19 Apr. 1980; Guido Nonveiller leg.; traps for endogean fauna baited with rotten meat; IZFB-21/1.

\section{Paratypes}

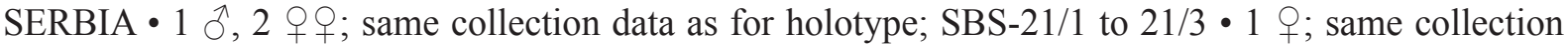
data as for holotype; IZFB-21/2 2 ô, 2 우우 ; same collection data as for holotype; CDP-21/1 to 21/4 - 10 ડ̄ $\partial^{\lambda}, 14$ 우; western Serbia, town of Ljubovija, Mt Povlen, Debelo Brdo saddle, village of Gornje

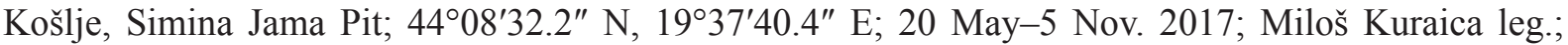
pitfall trapping; IZFB-21/3 to 21/26 2 ते 1 क; same locality as for preceding; $31 \mathrm{Dec}$. 2010; Iva Njunjić leg.; pitfall trapping; SBS-21/4 to 21/6・18 $\widehat{\jmath}, 39$ 우; same collection data as for preceding; CDP-21/5 to 21/61 (Fig. 2).

\section{Description}

HabItus. Body elliptical, TL R 2.51-2.80 mm (R 2.51-2.73 mm in males, R 2.67-2.80 mm in females), reddish-brown in colour, shiny, pubescent, with a fine punctuation (Fig. 2A).

HEAD. Short, wide, slightly wider than long (HL/HW M 0.97), without eyes (Fig. 2A). Antennae long and slender, apically gradually widened and flattened, ending slightly after basal third of elytra in males 

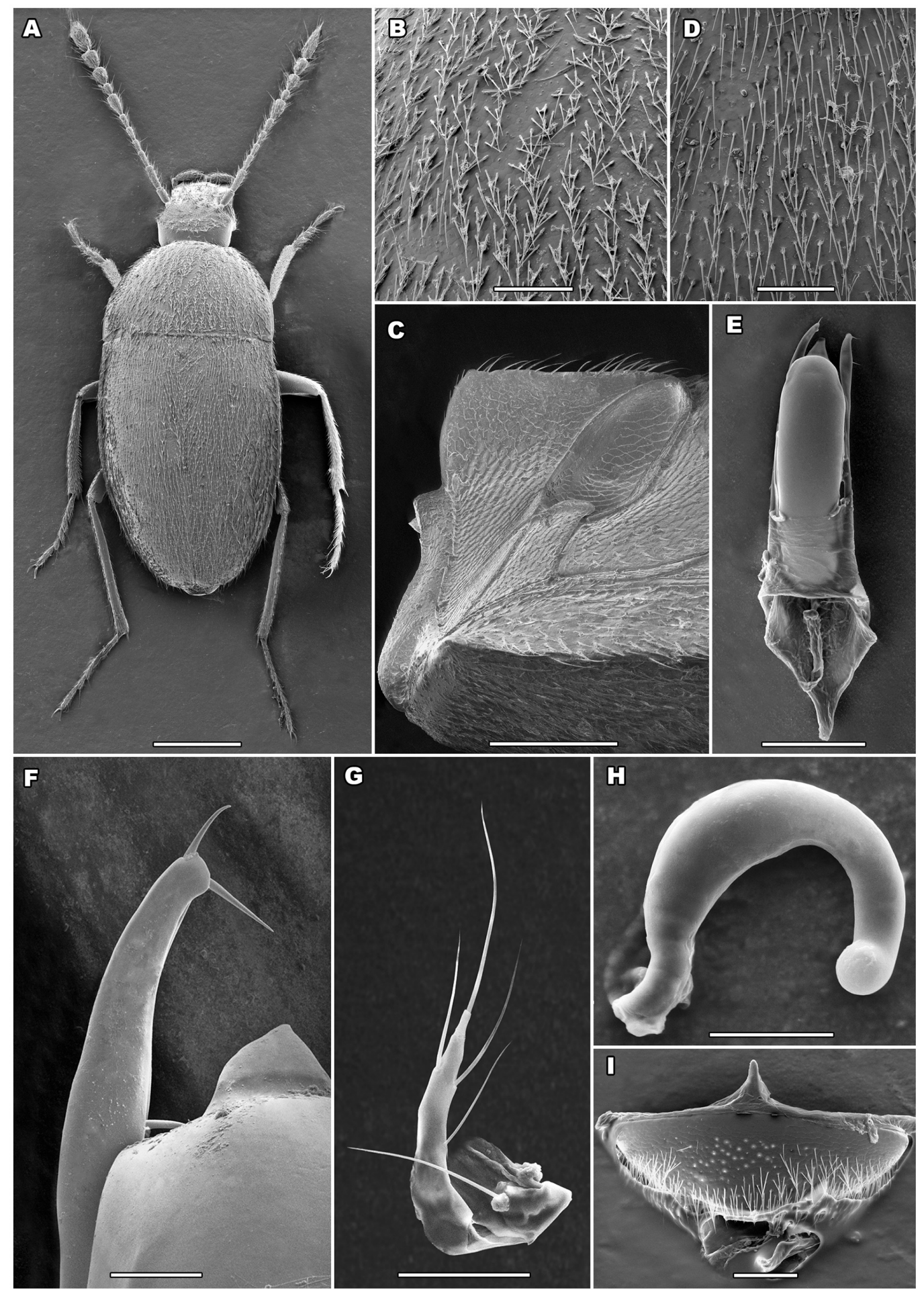

Fig. 2. Bozidaria serbooccidentalis Ćurčić \& Pavićević gen. et sp. nov. from the Simina Jama Pit, village of Gornje Košlje, Debelo Brdo saddle, Mt Povlen, near the town of Ljubovija, western Serbia. A-F. Paratype male (IZFB-21/3). A. Habitus (dorsal view). B. Surface of pronotum (dorsal view). C. Mesosternal carina (lateral view). D. Surface of elytra (dorsal view). E. Aedeagus (dorsal view). F. Left paramere apex (dorsal view). G-I. Paratype female (IZFB-21/4). G. Left gonostylus (dorsal view). H. Spermatheca (lateral view). I. Abdominal segment VIII (ventral view). Scale bars: $A=500 \mu \mathrm{m}$; $\mathrm{B}, \mathrm{D}, \mathrm{G}, \mathrm{I}=100 \mu \mathrm{m} ; \mathrm{C}, \mathrm{E}=200 \mu \mathrm{m} ; \mathrm{F}=25 \mu \mathrm{m} ; \mathrm{H}=50 \mu \mathrm{m}$. 
or slightly prior to basal third of elytra in females. Antennomere II longer than antennomere I (A1/A2 M 0.795). A3/A2 M 0.67. A3/A5 M 1.24. Antennomeres IV-VI of similar length, of which IV narrowest and VI widest. Antennomere VII apically widened. A7/A6 M 1.56. Antennomere VIII slightly longer than half of antennomere VII (A7/A8 M 1.53), oval, somewhat elongate (A8LW M 1.52). Antennomere IX somewhat elongate, gradually widened distally (A9LW M 1.47). A9/A8 M 1.52 in males, M 1.42 in females. Antennomere X slightly longer than wide (A10LW M 1.24), more widened apically. Antennomere XI slender, ovoid, apically pointed, more elongate in males (A11LW M 2.45) than in females (A11LW M 1.97), as long as preceding two antennomeres combined or slightly shorter than the latter. Occipital carina present. Hairs yellow, erect. Microsculpture composed of small isodiametric meshes.

THORax. Pronotum transverse, widest sub-basally, almost twice as wide as long (PL/PW M 0.59) (Fig. 2A). Lateral pronotal margins arcuate, rounded medially, sub-parallel prior to hind pronotal angles. Pronotal base more than twice as long as anterior pronotal margin (PB/AM M 2.13). Both anterior pronotal margin and pronotal base convex medially, the latter less pronouncedly. PL+EL/AL M 1.63 in males, M 1.89 in females. Fore angles prominent, obtuse, rounded, hind angles sharp, rounded, prominent, directed backwards. Microsculpture of pronotum composed of large isodiametric meshes. Hairs yellow, recumbent (Fig. 2B). Pronotal disc weakly convex. Mesosternal carina high, obtuse-angled, anterior margin strongly convex, posterior margin barely convex, almost straight, with hairs and teeth (Fig. 2C). Mesosternal carina with an apical tooth. Ventral border of mesosternal carina not grooved.

ELYTRA. Elongate (EL/EW M 1.38 in males, M 1.40 in females), more than 2.5 times as long as pronotum (EL/PL M 2.65), obovoid, sub-parallel below humeral angles, weakly narrowed basally, rounded medially, narrowed apically (Fig. 2A). Apex rounded. Sutural striae absent. Scutellum small, triangular. Elytra widest between basal third and mid-length. Microsculpture composed of large isodiametric meshes. Hairs yellow, recumbent (Fig. 2D). Elytral disc convex. Pygidium not completely covered by elytra.

Legs. Elongate and thin, with hairs (Fig. 2A). Tibiae with a few spines laterally. Anterior tarsi tetramerous in both genders, somewhat dilated in males (P1LW M 1.825 in males, M 1.88 in females).

ABdomen. Median lobe of aedeagus elongate, thin, sub-parallel, sub-apically rounded (Figs 2E, 3A). Apex elongate, triangular. Basal bulb relatively narrow, elongate, with a sub-triangular basal projection. Copulatory piece weakly chitinised, consisting of a basal phanera, median paired stripes and apical paired sclerotizations. Median lobe proximally straight, distally relatively curved, gradually narrowed distally in lateral view (Fig. 3B). Basal bulb narrow in lateral view. Parameres slender, thin, longer than median lobe, sub-terminally widened, terminally narrowed, apex slightly dilated, proximally arcuate and distally straight in lateral view, with three setae: one apical terminal, one apical inner and one sub-apical inner (Fig. 2F). Two apical parameral setae close-set. Parameral apices directed inwards. Parameres basally slightly curved, distally relatively straight in lateral view, sub-terminally widened, terminally narrowed in lateral view (Fig. 3B).

GonostyLI. Almost straight, elongate, thin, with one apical seta, three inner setae and one outer seta (Fig. 2G).

SpermatheCA. Small, curved, widest in proximal third, apically sub-spherical (Fig. 2H).

Female abdominal sternite VIII. Large, transverse, setose both medially and distally, with a narrow, pointed anterior process. Microsculpture consisting of transverse polygonal meshes (Fig. 2I). 


\section{Bionomy, distribution and type locality}

The type specimens were collected in traps for endogean fauna (cans) baited with rotten meat placed in the deep soil on Mt Bobija, near the town of Ljubovija, western Serbia, as well as by pitfall trapping with rotten meat as bait in the deep, totally dark parts of the Simina Jama Pit, village of Gornje Košlje, Debelo Brdo saddle, Mt Povlen, near the town of Ljubovija, western Serbia (Fig. 9). The type locality on Mt Bobija is located on its northern slope, at an altitude of $1000 \mathrm{~m}$ a.s.l., in a beech forest, close to several

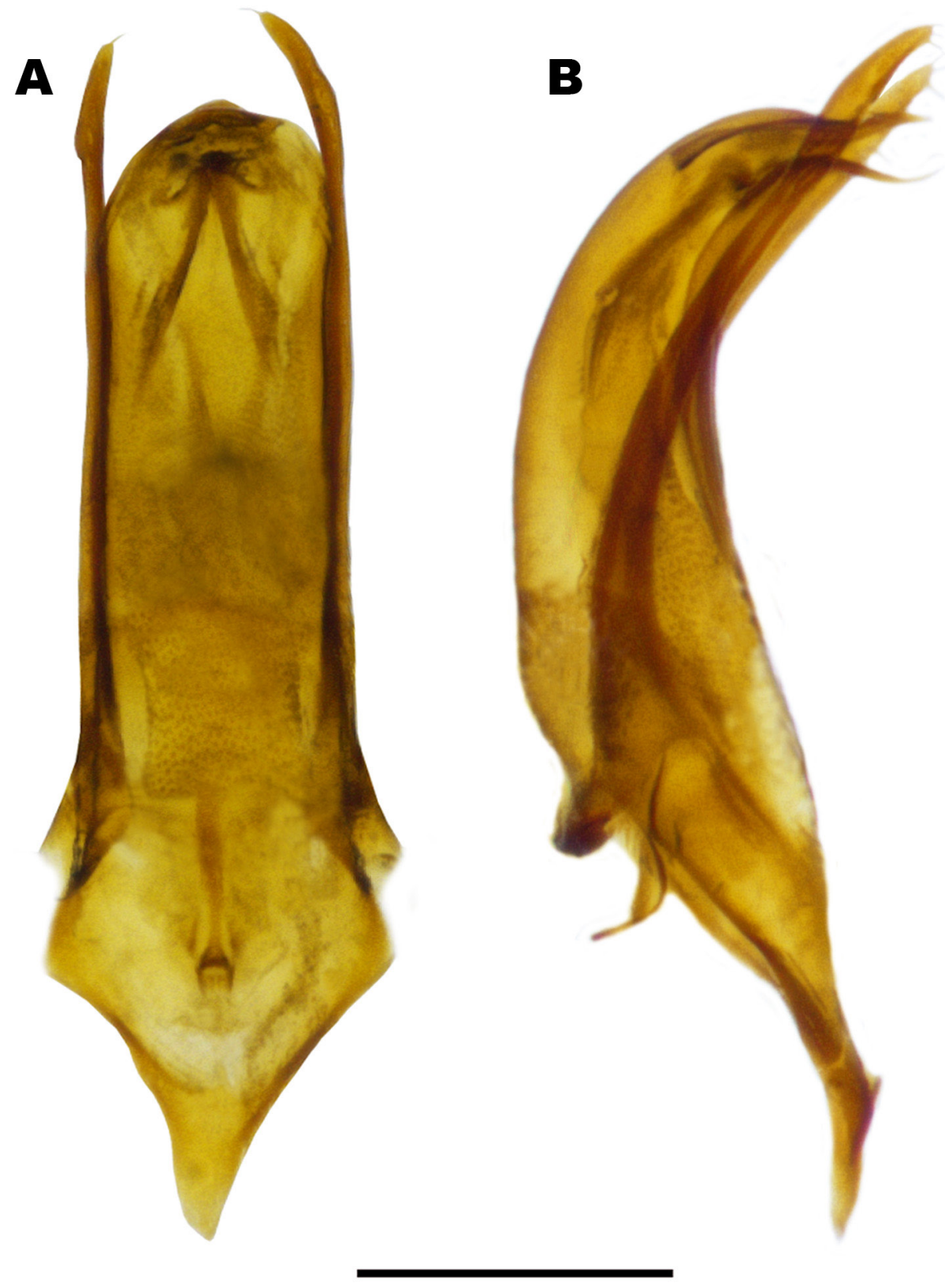

Fig. 3. Bozidaria serbooccidentalis Curčić \& Pavićević gen. et sp. nov. from the Simina Jama Pit, village of Gornje Košlje, Debelo Brdo saddle, Mt Povlen, near the town of Ljubovija, western Serbia. Holotype male (IZFB-21/1), aedeagus. A. Dorsal view. B. Lateral view. Scale bar $=200 \mu \mathrm{m}$. 
streams. The entrance of the Simina Jama Pit is situated at $920 \mathrm{~m}$ a.s.1., the total length of its investigated channels is $270 \mathrm{~m}$, while its depth is $56 \mathrm{~m}$. It starts with a $31-\mathrm{m}$ long vertical passage, which splits into two horizontal channels - left and right (Anđelić et al. 2011). Beetle specimens were found at the end and in the middle of the left horizontal channel with a clay muddy substrate and rocks, on the vertical limestone walls and floor with a high level of humidity (presence of trickling water). The places where the specimens were found in the pit are shown in Fig. 4. It is assumed that the species is actually endogean, as is the case with some other leiodid taxa (e.g., Magdelainella spp.), which inhabit the soil beneath deeply sunken rocks and forest detritus, but can also be found in caves and pits (Pavićević et al. 2012).

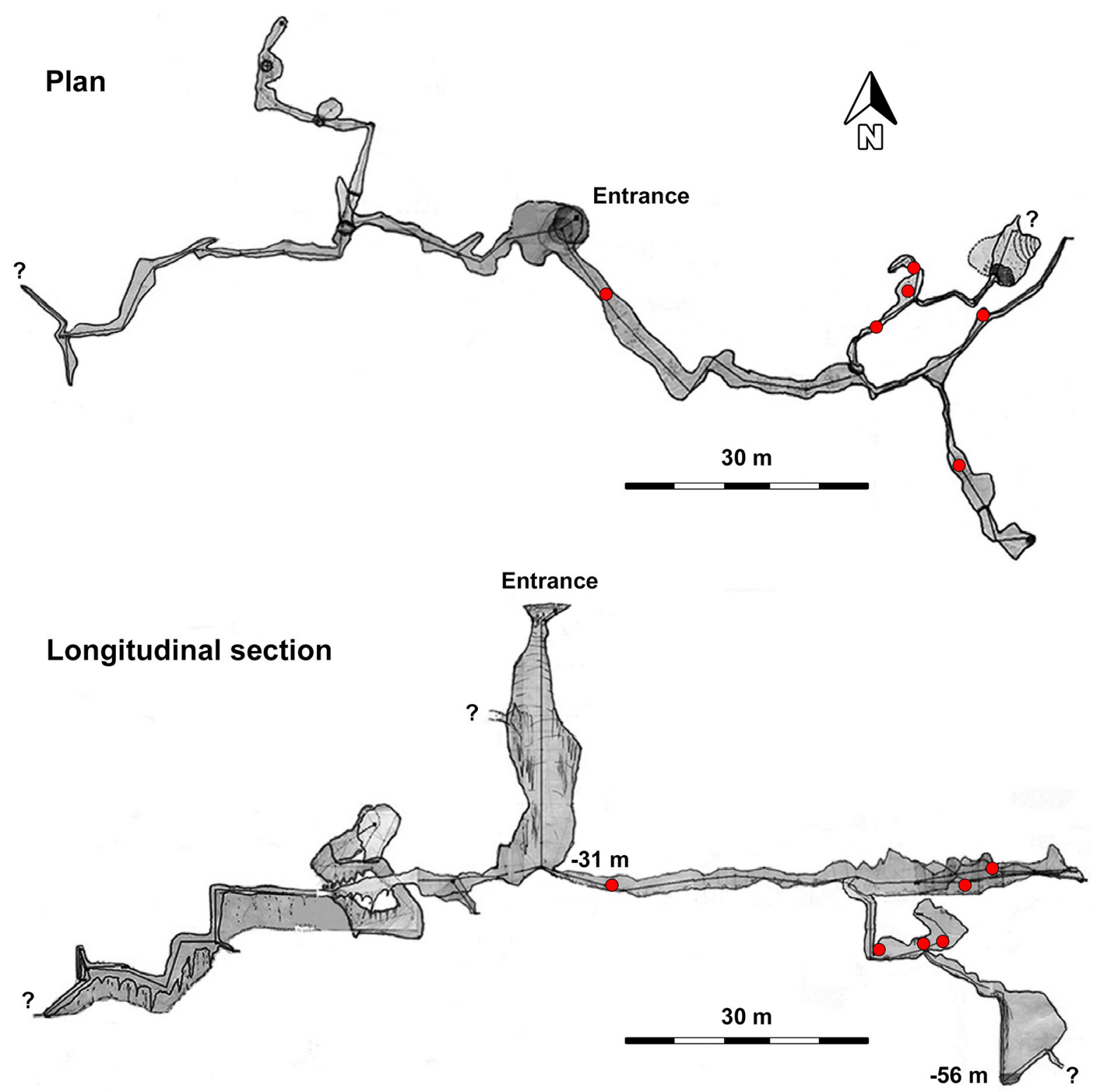

Fig. 4. A plan and a longitudinal section of the Simina Jama Pit, village of Gornje Košlje, Debelo Brdo saddle, Mt Povlen, near the town of Ljubovija, western Serbia (modified after Anđelić et al. 2011). The red circles indicate the places where specimens of Bozidaria serbooccidentalis Curčić \& Pavićević gen. et sp. nov. were found. 
Genus Proleonhardella Jeannel, 1910

Proleonhardella (Proleonhardella) tarensis Ćurčić \& Pavićević sp. nov. urn:lsid:zoobank.org:act:E1B53D50-0C09-4E5C-AFB1-AC9F6EBBD426

Figs 5-6

\section{Diagnosis}

Proleonhardella (Proleonhardella) tarensis sp. nov. is most closely related to $P$. (P.) hirtella (from several caves and pits near the towns of Prijepolje (southwestern Serbia) and Pljevlja (northern Montenegro)), $P$. (P.) weiratheri (Reitter, 1913) (from the Vrteljka Cave, village of Đipi, Mt Sjemeć, near the town of Višegrad, eastern Bosnia and Herzegovina) and P. (P.) neumanni (Apfelbeck, 1901) (from a small unnamed cave, village of Podromanija, near the town of Sokolac, eastern Bosnia and Herzegovina) (Fig. 9) (Perreau 2000; Pavićević et al. 2012). Another congener from Serbia, P. (P.) remyi (from caves and pits in the area of Kamena Gora and near the towns of Prijepolje, Priboj (southwestern Serbia) and Pljevlja (northern Montenegro)), is of bathyscioid shape ( $P$. $(P$.$) tarensis sp. nov. is more elongate and$ of oval shape), it is significantly longer than the new species (TL R $3.0-3.5 \mathrm{~mm}$ vs $2.185-2.435 \mathrm{~mm}$ in $P$. (P.) tarensis sp. nov.) and has a quite different shape of aedeagus (stout, with a rounded apex, longer than parameres vs elongate, with a pointed apex, shorter than parameres in $P$. (P.) tarensis sp. nov.), indicating that these two species are not closely related (Jeannel 1934; Ćurčić et al. 2008a).

The new species differs from its closest congeners in the TL R $(2.185-2.435 \mathrm{~mm}$ vs $1.6-1.8 \mathrm{~mm}$ in $P$. (P.) hirtella and $1.6-2.0 \mathrm{~mm}$ in $P$. (P.) weiratheri), antennal length (ending prior to basal third of elytra vs reaching only basal quarter of elytra in $P$. (P.) hirtella and exceeding middle of body in $P$. $(P$.) weiratheri), A1/A2 M (0.76 vs 0.80 in $P$. ( $P$.) neumanni), A7/A6 M (1.66 vs 1.50 in $P$. ( $P$.) hirtella), A7/A8 R (1.75-2.00 vs 3.00 in $P$. (P.) hirtella), A11/A9+A10 M (0.90 vs 1.00 in $P$. ( $P$.) weiratheri), shape of antennomere VIII (oval and slightly longer than wide in males and spherical in females vs as long as wide in males and almost transverse in females in $P .(P$.) weiratheri), shape of antennomeres IX and $\mathrm{X}$ (slightly longer than wide vs as long as wide in $P$. $(P$.) hirtella), position of maximum width of pronotum (sub-basally vs at base in $P$. $(P$.) hirtella and $P$. $(P$.) weiratheri), shape of mesosternal carina (obtuse-angled vs almost right-angled in $P$. (P.) neumanni), shape of elytra (narrowed basally vs parallel basally in $P$. ( $P$.) hirtella and $P$. ( $P$.) weiratheri and clearly sinuate basally in $P$. $(P$.) neumanni), EL/EW (R 1.31-1.39 vs M 1.75 in $P$. (P.) weiratheri), position of maximum width of elytra (slightly after basal third vs prior to middle in $P$. $(P$.) neumanni), and shape of aedeagus (less elongate, with wider apex and larger basal bulb vs more elongate, with narrower apex and smaller basal bulb in $P$. (P.) hirtella) (Apfelbeck 1901; Reitter 1913; Jeannel 1924, 1934).

\section{Etymology}

The species is named after Mt Tara in western Serbia, where its type locality is situated.

\section{Type material}

\section{Holotype}

SERBIA - đ; western Serbia, town of Bajina Bašta, Mt Tara, village of Kaluđerske Bare, Pit 4-1-3-27;

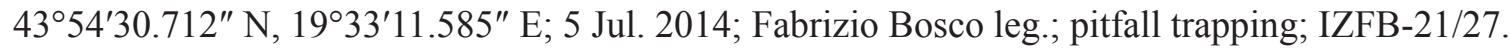

\section{Paratypes}

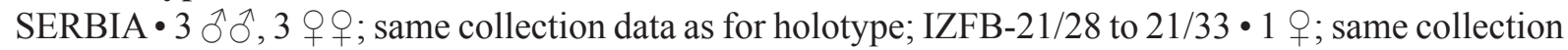
data as for holotype; SBS-21/7 1 ภ, 2 우; western Serbia, town of Bajina Bašta, Mt Tara, village of

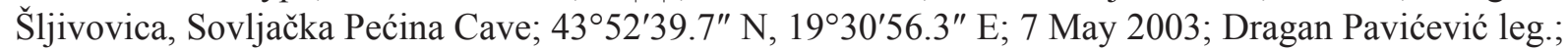

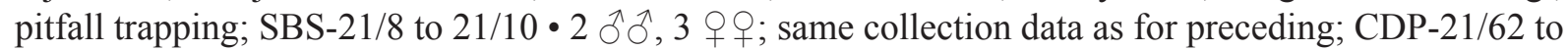
21/66 (Fig. 5). 


\section{Description}

HABITUS. Body oval, relatively elongate, TL R 2.185-2.435 mm (R 2.185-2.32 mm in males, $2.435 \mathrm{~mm}$ in females), colour brownish-red (one teneral female specimen yellowish), shiny, pubescent and with a fine punctuation (Fig. 5A).

HEAD. Short, wide, slightly longer than wide (HL/HW R 1.00-1.06), anophthalmous (Fig. 5A). Antennae long and narrow, ending prior to basal third of elytra, apically widened and flattened. Antennomere II longer than antennomere I (A1/A2 M 0.76). Antennomeres III-VI small, narrow, of similar shape and length. A3/A2 M 0.58. A3/A5 M 1.19. Antennomere VII apically widened, obovoid. A7/A6 M 1.66. Antennomere VIII half as long as antennomere VII, oval and slightly longer than wide in males (A8LW M 1.31), while somewhat shorter (A7/A8 M 1.75), nearly as long as wide (A8LW M 1.04) and spherical in females. Antennomeres IX and X slightly longer than wide (A9LW M 1.28 and A10LW M 1.21, respectively), apically widened. A9/A8 M 1.60 in males, 2.00 in females. Antennomere XI ovoid, twice as long as wide in males, somewhat shorter in females (A11LW M 1.92), slightly shorter than two preceding antennomeres combined (A11/A9+A10 M 0.90). Occipital carina present. Hairs yellow, erect. Microsculpture composed of small isodiametric meshes.

Thorax. Pronotum transverse, almost twice as wide as long (PL/PW M 0.59), widest sub-basally (Fig. 5A). Lateral pronotal margins arcuate, most rounded medially, almost sub-parallel prior to hind pronotal angles. Anterior pronotal margin somewhat convex medially, base almost straight, around twice as long as anterior pronotal margin (PB/AM M 1.985). PL+EL/AL M 1.685 in males, 1.94 in females. Fore angles prominent, obtuse, rounded, hind angles sharp, rounded, prominent, directed backwards. Microsculpture of pronotum composed of large isodiametric meshes. Hairs yellow, recumbent (Fig. 5B). Pronotal disc weakly convex. Mesosternal carina high, obtuse-angled, anterior margin convex, posterior margin straight, setose and with unpronounced teeth (Fig. 5C). Mesosternal carina with an apical tooth.

Elytra. Elongate (EL/EW M 1.39 in males, 1.31 in females), more than twice as long as pronotum (EL/ PL M 2.46), obovoid, sub-parallel below humeral angles, conspicuously narrowed basally, rounded medially, attenuated apically (Fig. 5A). Apex rounded. Sutural striae absent. Scutellum small, triangular. Elytra widest slightly after basal third. Microsculpture composed of large isodiametric meshes. Hairs yellow, recumbent (Fig. 5D). Elytral disc gently convex apically, more steeply distally. Pygidium completely covered by elytra.

Legs. Moderately elongate and thin, with hairs (Fig. 5A). Tibiae with a few spines. Anterior tarsi tetramerous in both genders, dilated in males (P1LW M 1.50 in males, 2.00 in females).

AвDOMEN. Median lobe of aedeagus elongate, thin, sub-parallel, sub-terminally somewhat widened, then narrowed apically (Figs 5E, 6A). Apex triangular. Basal bulb large, elongate, with a sub-triangular basal projection. Copulatory piece weakly chitinised, consisting of a basal phanera, median paired stripes and distal paired sclerotizations. Median lobe proximally weakly curved, distally more curved, gradually narrowed distally in lateral view (Fig. 6B). Basal bulb relatively narrow in lateral view. Parameres slender, thin, longer than median lobe, sub-terminally widened, terminally narrowed, basally arcuate and distally straight in lateral view, with three setae: one apical terminal, one apical inner and one sub-apical inner (Fig. 5F). Two apical parameral setae close-set. Parameral apices directed inwards. Parameres basally slightly curved, distally relatively straight, sub-terminally widened, terminally narrowed, apically directed downwards in lateral view (Fig. 6B).

GonostyLI. Straight, elongate, thin, with one apical seta, three inner setae and one outer seta (Fig. 5G).

SpermatheCA. Small, hook-like, widest in middle, apically sub-spherical (Fig. 5H). 

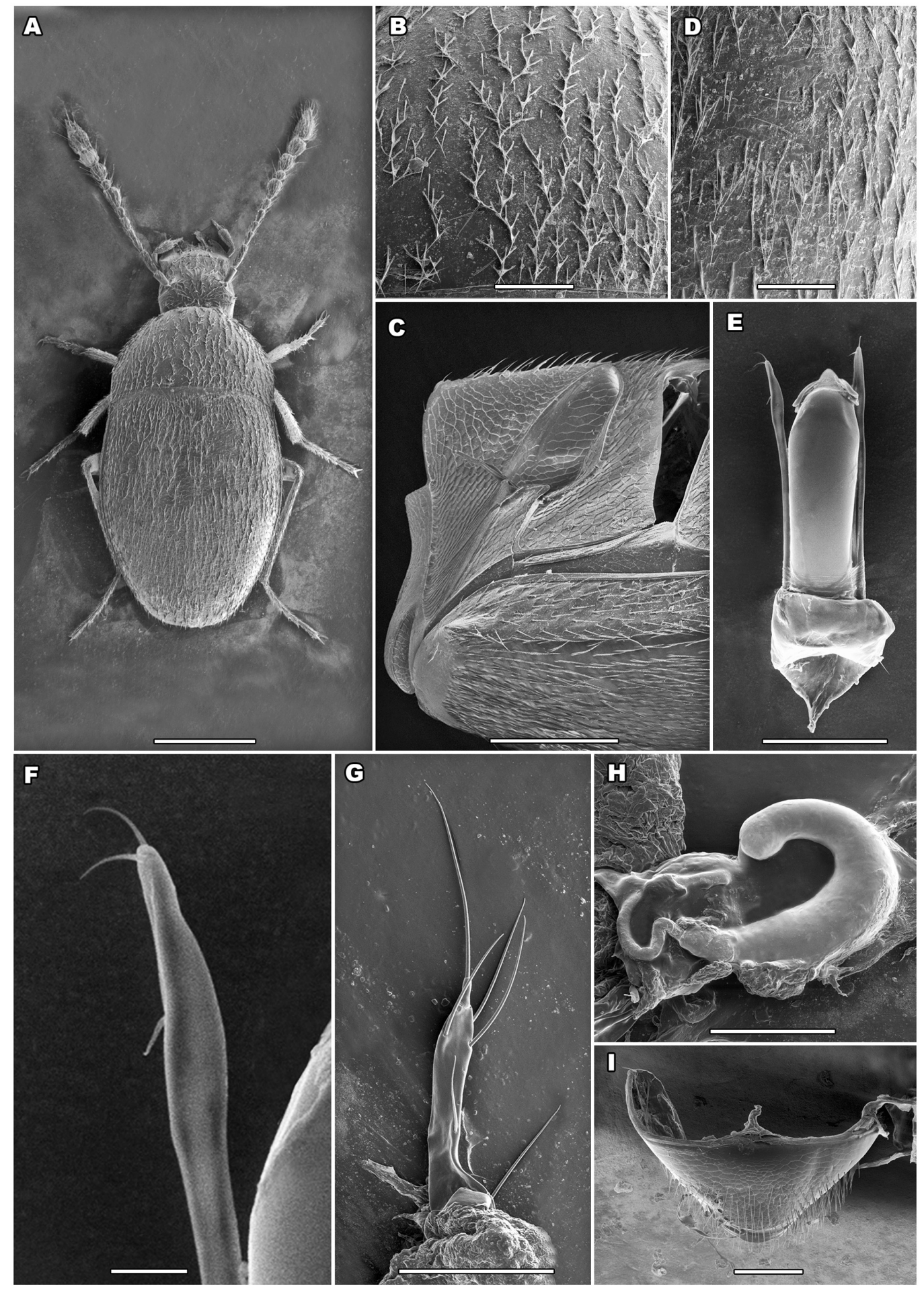

Fig. 5. Proleonhardella (Proleonhardella) tarensis Ćurčić \& Pavićević sp. nov. from Pit 4-1-3-27, village of Kaluđerske Bare, Mt Tara, near the town of Bajina Bašta, western Serbia. A-F. Paratype male (IZFB-21/28). A. Habitus (dorsal view). B. Surface of pronotum (dorsal view). C. Mesosternal carina (lateral view). D. Surface of elytra (dorsal view). E. Aedeagus (dorsal view). F. Left paramere apex (dorsal view). G-I. Paratype female (IZFB-21/29). G. Left gonostylus (dorsal view). H. Spermatheca (lateral view). I. Abdominal segment VIII (ventral view). Scale bars: A $=500 \mu \mathrm{m} ; \mathrm{B}, \mathrm{D}, \mathrm{G}, \mathrm{I}=100 \mu \mathrm{m}$; $\mathrm{C}, \mathrm{E}=200 \mu \mathrm{m} ; \mathrm{F}=25 \mu \mathrm{m} ; \mathrm{H}=50 \mu \mathrm{m}$. 
Female ABDOMinal sternite VIII. Large, transverse, setose in distal half, with a small, narrow anterior process. Microsculpture consisting of transverse polygonal meshes (Fig. 5I).

\section{Comparisons}

Proleonhardella $(P$.$) hirtella, P .(P$.$) weiratheri and P$. $(P$.$) tarensis sp. nov. are somewhat elongate and$ their aedeagus is narrower than in the remaining congeners, suggesting their specific position within the genus. Based on these features, they are similar to Bozidaria gen. nov., but are much shorter (TL R 1.6$1.8 \mathrm{~mm}$ in $P$. (P.) hirtella, $1.6-2.0 \mathrm{~mm}$ in $P$. (P.) weiratheri and $2.185-2.435 \mathrm{~mm}$ in $P$. (P.) tarensis sp. nov.

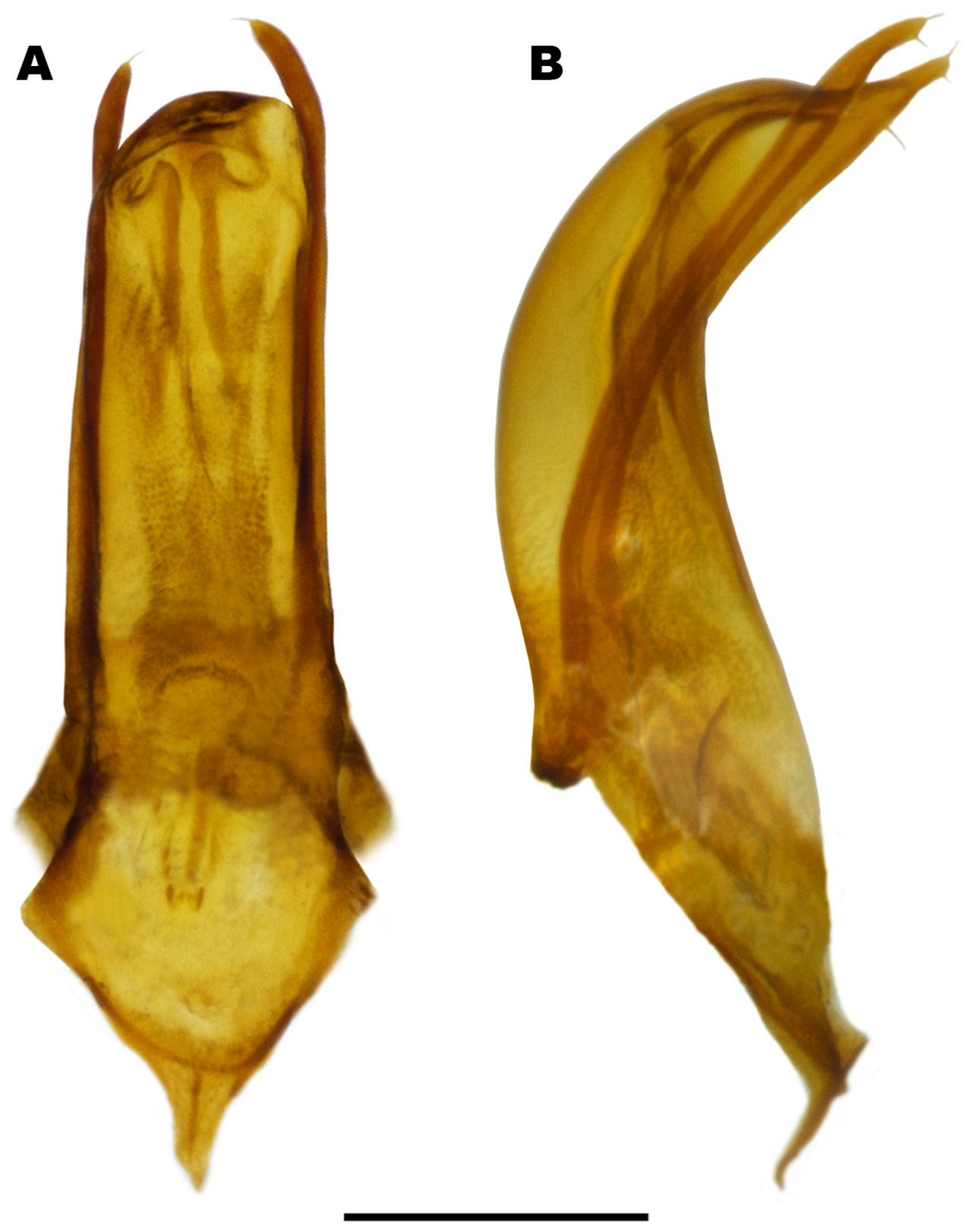

Fig. 6. Proleonhardella (Proleonhardella) tarensis Ćurčić \& Pavićević sp. nov. from Pit 4-1-3-27, village of Kaluđerske Bare, Mt Tara, near the town of Bajina Bašta, western Serbia. Holotype male (IZFB-21/27), aedeagus. A. Dorsal view. B. Lateral view. Scale bar $=200 \mu \mathrm{m}$. 
vs $2.51-2.80 \mathrm{~mm}$ in B. serbooccidentalis gen. et sp. nov.), share other characteristics of Proleonhardella and additionally differ from the new genus in the shape of the antennae, the median lobe of the aedeagus, the basal bulb and its basal projection.

Proleonhardella $(P$.$) tarensis sp. nov. and its closest relatives (P .(P$.$) hirtella, P .(P$.$) weiratheri$ and $P$. $(P$.) neumanni) share the presence of elongate, somewhat convex elytra, which are more than twice as long as the pronotum. Furthermore, the new species, $P$. (P.) hirtella and $P$. ( $P$.) weiratheri have a somewhat elongate body shape, while the body shape in the remaining Proleonhardella taxa
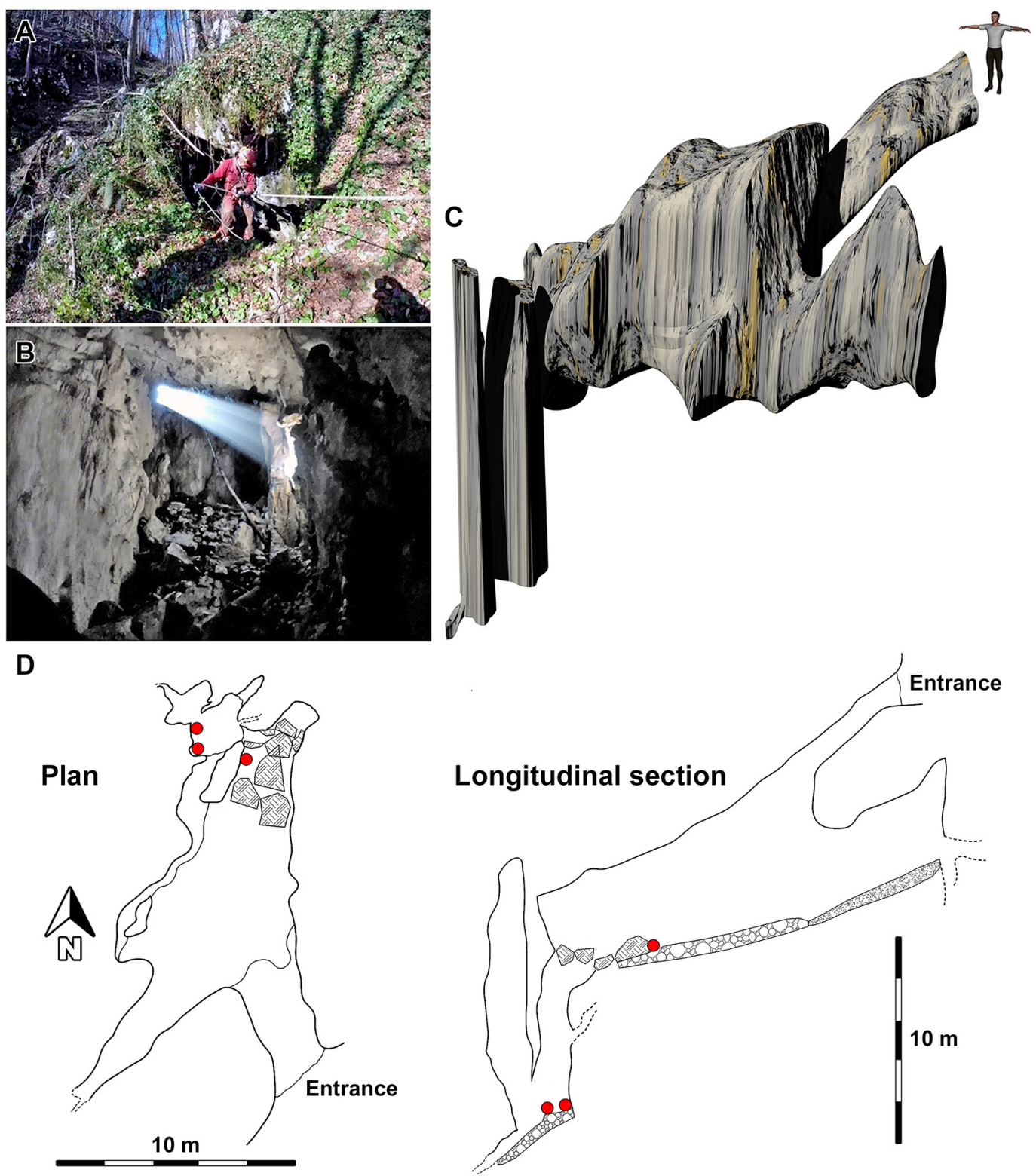

Fig. 7. Pit 4-1-3-27, village of Kaluđerske Bare, Mt Tara, near the town of Bajina Bašta, western Serbia (modified after Bosco 2016). A. Entrance. B. A chamber in which one type specimen of Proleonhardella (Proleonhardella) tarensis Ćurčić \& Pavićević sp. nov. was collected. C. A 3D view. D. A plan and a longitudinal section. The red circles indicate the places where specimens of $P$. $(P$.) tarensis Ćurčić \& Pavićević sp. nov. were found. 
is more or less bathyscioid. These three species have an elongate aedeagus, contrary to other known congeners, in which the aedeagus is more or less short (Jeannel 1924, 1934). The shape of the aedeagus of $P$. (P.) neumanni wasn't mentioned in the description of the species or elsewhere (Apfelbeck 1901; Jeannel 1924).
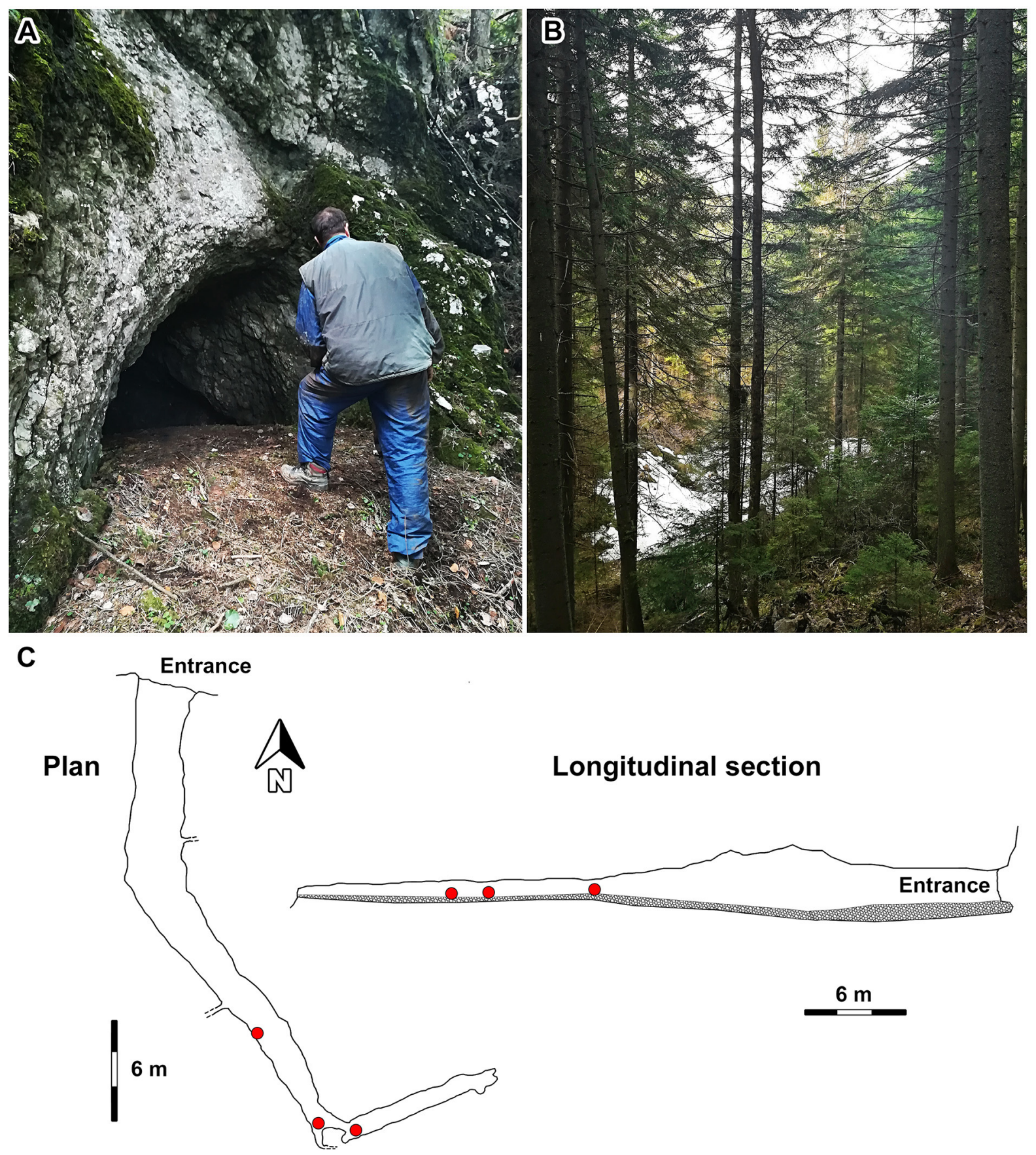

Fig. 8. Sovljačka Pećina Cave, village of Šljivovica, Mt Tara, near the town of Bajina Bašta, western Serbia (modified after Bosco 2016). A. Entrance. B. Immediate surroundings (a coniferous forest and view of the Sovljak stream). C. A plan and a longitudinal section. The red circles indicate the places where specimens of $P$. (P.) tarensis Ćurčić \& Pavićević sp. nov. were found. 


\section{Bionomy, distribution and type locality}

The type specimens were gathered using pitfall traps with rotten meat as bait in Pit 4-1-3-27 in the village of Kaluđerske Bare, as well as in the Sovljačka Pećina Cave in the village of Šljivovica (Fig. 9). Both localities are situated on Mt Tara, near the town of Bajina Bašta, western Serbia. Beetles were found in the inner (from the middle to the innermost point), totally dark parts of the cave sites. The entrance of Pit 4-1-3-27 is situated at $868 \mathrm{~m}$ a.s.l., the total length of its investigated channels is 28 $\mathrm{m}$, while its depth is $22 \mathrm{~m}$. After a short vertical passage, the pit opens into a large chamber which contains big rocks at its lowest part. At this point another vertical passage starts, at the end of which is situated a small, moist semicircular chamber with a clay substrate and rocks (Bosco 2016). Beetle specimens were found in the inner part of the larger chamber, among rocks, and in the smaller chamber with a clay substrate and rocks, on the floor and vertical limestone walls with a high level of humidity (presence of trickling water). The entrance of the Sovljačka Pećina Cave is situated at $1080 \mathrm{~m}$ a.s.l. and its total length is $43 \mathrm{~m}$ (Bosco 2016). The cave is located in a coniferous forest in a valley where the Sovljak stream runs. It is entirely horizontal and consists of a single channel which is oriented to the left. Its height is slightly decreasing towards the end. Beetle individuals were found in the inner

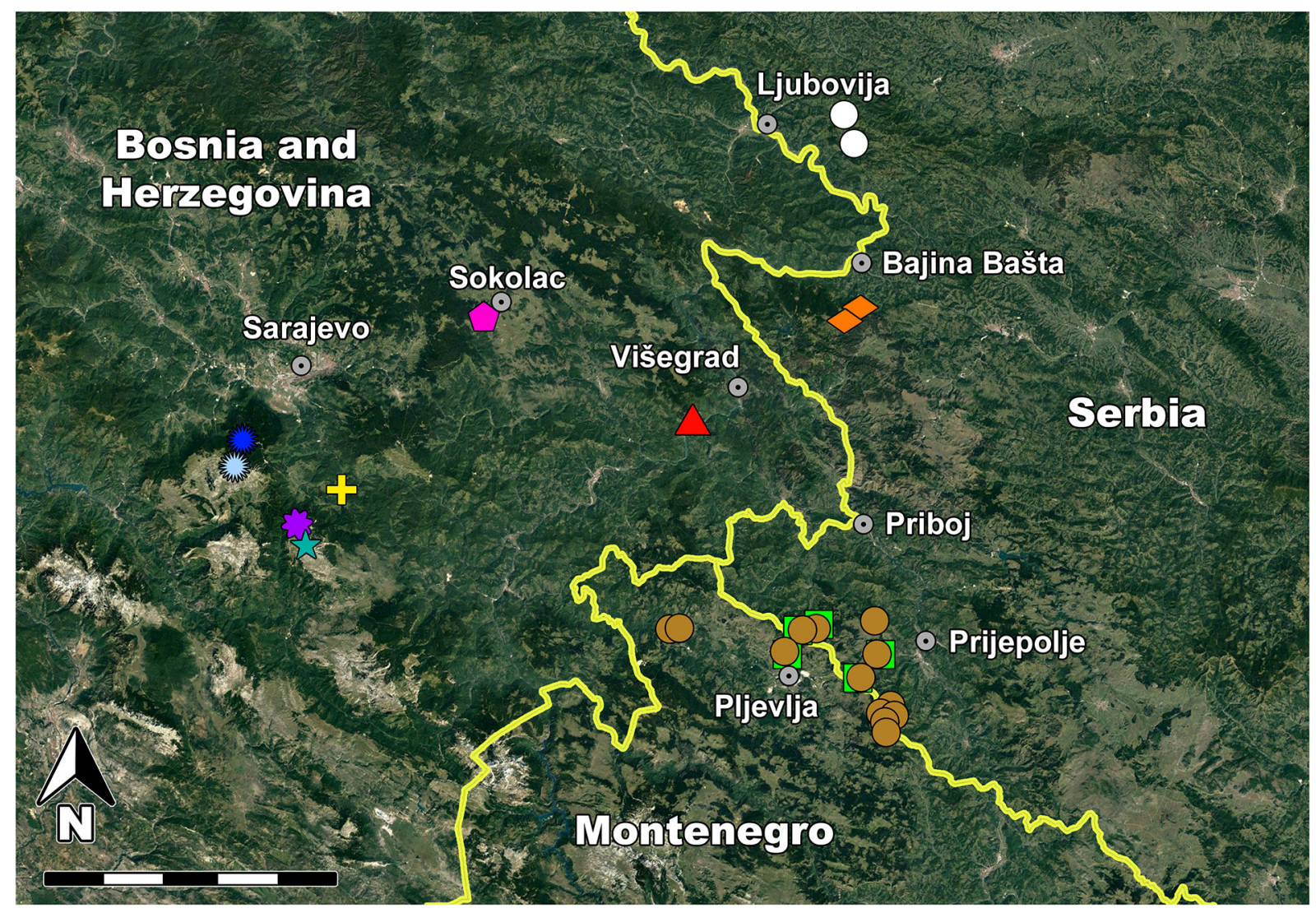

Fig. 9. Map of the distribution of taxa of the genera Bozidaria Ćurčić \& Pavićević gen. nov. and Proleonhardella Jeannel, 1910. White circles: B. serbooccidentalis Ćurčić \& Pavićević gen. et sp. nov. Turquoise star: P. (Pholeuonillus) adolfi (Reitter, 1911). Light blue sun: P. (Proleonhardella) matzenaueri matzenaueri (Apfelbeck, 1907). Dark blue sun: P. (P.) matzenaueri ottonis Müller, 1917. Purple flower: P. (P.) leonhardi (Breit, 1913). Yellow cross: P. (P.) apfelbecki Jeannel, 1924. Brown circles: $P$. (P.) remyi Jeannel, 1934. Green squares: $P$. (P.) hirtella Jeannel, 1934. Pink pentagon: P. (P.) neumanni (Apfelbeck, 1901). Red triangle: P. (P.) weiratheri (Reitter, 1913). Orange rhombuses: $P$. (P.) tarensis Ćurčić \& Pavićević sp. nov. Scale bar $=50 \mathrm{~km}$. 
part of the cave, on the floor among rocks, both on limestone and clay substrate, where a high level of humidity (presence of trickling water) was evident. Images of the cave localities and the places where the specimens were found in the caves are shown in Figs 7-8. The new species is most probably endogean and is likely to be found outside caves as well - in the deep soil strata and other speleological sites in the surroundings.

\section{Key to the taxa of the genus Proleonhardella Jeannel, 1910}

(modified after Jeannel 1924) (Figs 9-10)

1. Body more elongate, elliptical. Pronotum as wide as elytra, well constricted basally. Pronotal lateral margins well-rounded backwards. Mesosternal carina very low. Elytral punctuation rough and deep (subgenus Pholeuonillus Breit, 1913). Endogean, Mt Treskavica, southern Bosnia and Herzegovina

P. (Pholeuonillus) adolfi (Reitter, 1911)

- Body less elongate, oval. Pronotum narrower than elytra, weakly constricted basally. Pronotal lateral margins weakly rounded backwards. Elytral punctuation fine. Mesosternal carina elevated, angled (subgenus Proleonhardella Jeannel, 1910)

2. Elytra shorter, more convex, less than twice as long as pronotum (Fig. 10A) ……………............ 3

- Elytra longer, less convex, more than twice as long as pronotum (Fig. 10B) ................................. 6

3. Body of oval shape, longer (TL 1.8-2.2 mm). Antennae short, not reaching middle of body. Antennomere III not longer than antennomere V. Antennomere VIII globular in males (Fig. 10C). Cavernicolous, Mts Bjelašnica and Igman, central Bosnia and Herzegovina [P. (Proleonhardella) matzenaueri (Apfelbeck, 1907)]

- Body of subglobular shape, shorter (TL less than $1.8 \mathrm{~mm}$ ). Antennae long, reaching middle of body. Antennomere III longer than antennomere V. Antennomere VIII slightly elongate in males (Fig. 10D)

4. Body of almost regular oval shape, longer (TL 2.0-2.2 mm). Elytra not widened towards middle. Cavernicolous, Mt Bjelašnica, central Bosnia and Herzegovina

P. (Proleonhardella) matzenaueri matzenaueri (Apfelbeck, 1907)

- Body narrower anteriorly, shorter (TL 1.8-2.0 mm). Elytra clearly widened medially. Cavernicolous, Mt Igman, central Bosnia and Herzegovina

P. (Proleonhardella) matzenaueri ottonis Müller, 1917

5. Body more elongate and convex, longer (TL $1.5 \mathrm{~mm}$ ). Elytral punctuation finer and denser. Antennae shorter, with apical antennomeres thicker. Antennomere VIII barely longer than wide, antennomere $\mathrm{IX}$ as long as wide and antennomere $\mathrm{X}$ transverse in females. Cavernicolous, Mt Treskavica, southern Bosnia and Herzegovina P. (Proleonhardella) leonhardi (Breit, 1913)

- Body less elongate and convex, shorter (TL $1.3 \mathrm{~mm}$ ). Elytral punctuation stronger and less dense. Antennae longer, with apical antennomeres less thick. Antennomeres VIII, IX and X longer than wide in females. Cavernicolous, village of Trnovo, vicinity of the city of Sarajevo, central Bosnia and Herzegovina

P. (Proleonhardella) apfelbecki Jeannel, 1924

6. Body longer (TL 3.0-3.5 mm). Cavernicolous, Kamena Gora and vicinity of the towns of Prijepolje, Priboj and Pljevlja, southwestern Serbia and northern Montenegro

P. (Proleonhardella) remyi Jeannel, 1934

- Body shorter (TL less than $2.435 \mathrm{~mm}$ )

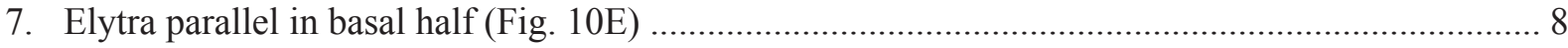

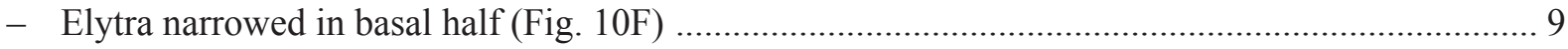


8. Pubescence long. Punctuation less fine. Apical antennomeres more widened. Pronotum less rounded. Apex of median lobe of aedeagus less bent ventrally. Elytral apex wide, obtuse and oblique. Cavernicolous, vicinity of the towns of Prijepolje and Priboj (southwestern Serbia) and Pljevlja (northern Montenegro)

P. (Proleonhardella) hirtella Jeannel, 1934

- Pubescence short. Punctuation finer. Apical antennomeres less widened. Pronotum more rounded. Apex of median lobe of aedeagus more bent ventrally. Elytral apex attenuated. Cavernicolous, Mt Sjemeć, eastern Bosnia and Herzegovina P. (Proleonhardella) weiratheri (Reitter, 1913)

9. A1/A2 M 0.80. Mesosternal carina almost right-angled. Elytral lateral margins below humeral angles clearly sinuate. Maximum width of elytra prior to middle. Cavernicolous, village of Podromanija, near the town of Sokolac, eastern Bosnia and Herzegovina

P. (Proleonhardella) neumanni (Apfelbeck, 1901)

- A1/A2 M 0.76. Mesosternal carina obtuse-angled. Elytral lateral margins below humeral angles sub-parallel. Maximum width of elytra slightly after basal third. Cavernicolous, Mt Tara, western Serbia P. (Proleonhardella) tarensis Ćurčić \& Pavićević sp. nov.

A

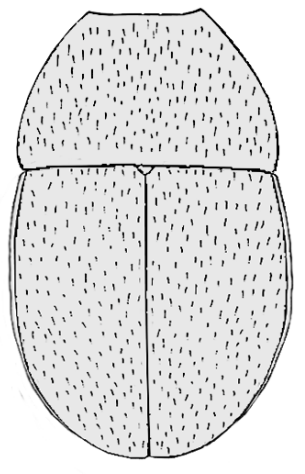

B

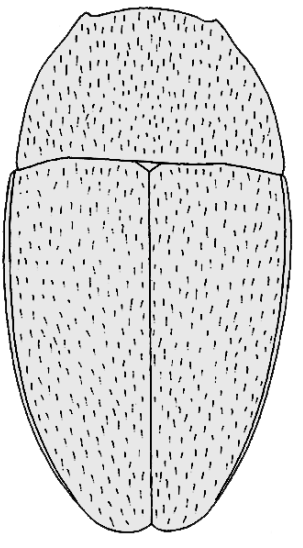

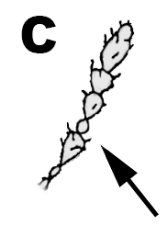

D

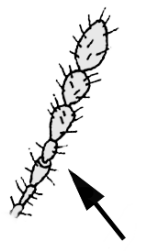

$\mathbf{E}$

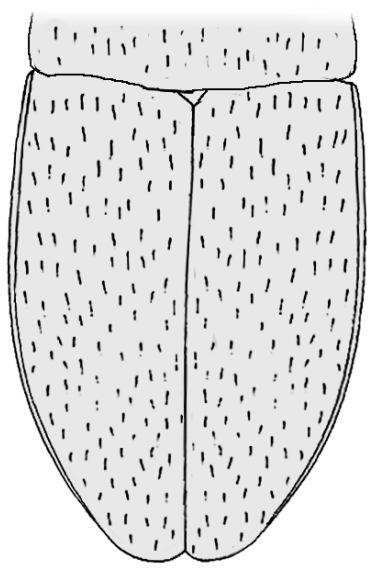

$\mathbf{F}$

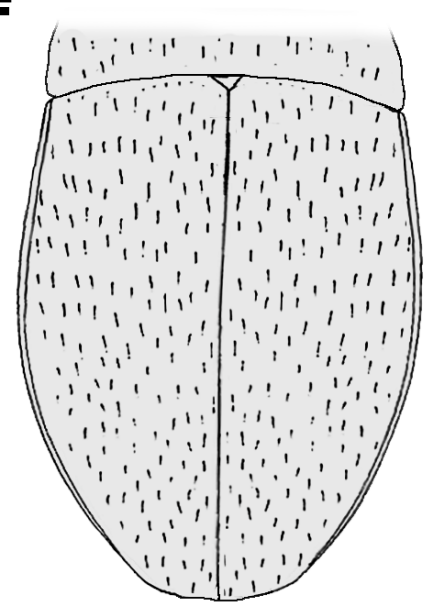

Fig. 10. Illustrations of morphological characters presented in the Key to the taxa of the genus Proleonhardella Jeannel, 1910 (after Jeannel 1924; Ćurčić et al. 2008a). A. Short elytra, less than twice as long as pronotum. B. Long elytra, more than twice as long as pronotum. C. Globular antennomere VIII in males. D. Slightly elongate antennomere VIII in males. E. Elytra parallel in basal half. F. Elytra narrowed in basal half. 


\section{Discussion}

It should be noted that a new genus of leptodirines belonging to the phyletic series of "Leonhardella" was recently established. Curčić et al. (2008a) considered the status of $P$. (P.) remyi and described a new genus, Serboleonhardella S. Ćurčić \& Schönmann, 2008, based on this taxon. Numerous differences between $P$. ( $P$.) remyi and other members of the genus Proleonhardella, some of which are quite significant (body size and form, antennal length, shape of certain antennomeres, form of median lobe and shape of parameral apex), indicated a need to separate $P$. (P.) remyi as a distinct genus or at least to a specific position within the genus Proleonhardella. This genus was not reported in the catalogues of Perreau (2015) and Hlaváč et al. (2017), nor has it been synonymized so far. Even Jeannel (1934) recognised that $P$. ( $P$.) remyi is quite remarkable for its large size compared to other congeners, which barely exceed $2 \mathrm{~mm}$ in length. The occurrence together of several congeners is a rare phenomenon in caves. Such is the case with $P$. $(P$.) remyi and $P$. $(P$.) hirtella, which were recorded together at five speleological sites in southwestern Serbia and northern Montenegro (Pavićević et al. 2012). This might also suggest that these taxa are indeed not congeneric. Additionally, Ćurčić et al. (2008a) proposed a new status for Pholeuonillus - as a full genus instead of a subgenus. Interestingly, Pholeuonillus was established by Breit (1913), who gave it generic rank. Later on, Jeannel (1924) treated it as a subgenus of Proleonhardella - a status that was maintained until now. It is recommended to study the taxa in question and other members of the genus Proleonhardella using molecular analyses in order to illuminate their phylogenetic relationships and to have their taxonomic status reconsidered and changed, if needed.

A series of high fluvial plateaus of the Inner Dinarides occur in western and southwestern Serbia (Zlatibor, Jabuka-Babine, etc.). According to their position in the area's relief, these plateaus are presumed to be of Pliocene age (Cvijić 1924, 1926). The palaeokarst in the areas of Mts Povlen and Tara was most probably formed at the same time as the Zlatibor plateau, in the second half of the Pliocene. Based on chronostratigraphic criteria by the International Commission on Stratigraphy (Gibbard et al. 2010; Gaudenyi \& Jovanović 2012), it is estimated that the palaeokarst in question is around 3-3.5 Ma old. It is likely that the karstic areas of Mts Povlen and Tara were connected with other karstic regions in their vicinity, favouring links between their subterranean faunas in old geological times, as evidenced by the occurrence of two new endogean and cavernicolous leptodirine taxa and their closest relatives in the surrounding areas.

The tribe Leptodirini has a Palaearctic distribution with its highest diversity located in the Mediterranean (Perreau 2000, 2015). It has undergone extensive diversification in the subterranean environment (Ribera et al. 2010). In their comprehensive molecular approach to the phylogeny of western Mediterranean Leptodirini, including the fauna of the Iberian Peninsula, Ribera et al. (2010) revealed that the main subterranean lineages of the tribe were separated before the Early Oligocene.

The Dinaric mountain chain has provided suitable conditions for subterranean life for millions of years, which resulted in the presence of a rich and diverse cave-dwelling fauna (Zagmajster et al. 2008; Kozel et al. 2020; Sendra \& Reboleira 2020). The leiodid beetle tribe Leptodirini is among the richest groups in the subterranean habitats (Sket 2005), comprising 175 species and 50 genera, most of which are endemic to the Dinarides. This mountain range is recognized for having the world's greatest species richness of subterranean fauna (Sket 2004; Culver et al. 2006; Deharveng et al. 2012). A very few studies dealing with phylogenetic relationships of certain subtribes within Dinaric Leptodirini exist. These studies were based only on morphology (Jeannel 1930; Perreau \& Pavićević 2008; Perreau 2019) and in most cases they have not been tested with molecular data. Only recently, Njunjić et al. (2018) commented on the suprageneric classification of eastern Mediterranean Leptodirini based on molecular phylogeny data. The clade comprising the subtribes Bathysciina Horn, 1880 and Bathysciotina V. Guéorguiev, 1974 was estimated to have originated in the Oligocene (ca $30 \mathrm{Ma}$ ago), while the tested genera of Bathysciina 
belonging to the phyletic series of "Leonhardella" (Leonhardella and Proleonhardella) separated more recently - in the Miocene (ca 20 Ma ago) (Njunjić et al. 2018).

As in the study of Njunjić et al. (2018) only two taxa belonging to the subtribe Bathysciina (phyletic series of "Leonhardella") were subjected to molecular characterization (Leonhardella (Leonhardellina) antennaria Apfelbeck, 1907 and $P$. (P.) remyi), more Dinaric genera of Bathysciina should be included in future molecular analyses to establish their phylogenetic relationships and to understand their origin and the colonization of the region by the subterranean representatives of the group. Discoveries of fascinating new genera of Bathysciina in the underground of the Dinaric karst in the last few decades (Nonveiller \& Pavićević 1999; Perreau 1999), including the one described herein, suggest that further investigations of the caves of the area are needed.

\section{Acknowledgements}

This study was financially supported by the Serbian Ministry of Education, Science and Technological Development (Contract No. 451-03-9/2021-14/200178), as well as by the Serbian Ministry of Education, Science and Technological Development and the Ministry of Science and Technology of the People's Republic of China (project "Mimetics of Insects for Sensing and Security", Grant I-2). The authors also acknowledge funding provided by the Institute of Physics Belgrade, through the grant by the Ministry of Education, Science and Technological Development of the Republic of Serbia. We are thankful to Assist. Prof. Dr Dragan Antić (Institute of Zoology, University of Belgrade - Faculty of Biology, Belgrade, Serbia) and Dr Iva Njunjić (Naturalis Biodiversity Center, Leiden, the Netherlands), who collected some of the scientific samples of Leptodirini that we used in this study. We are grateful to Assoc. Prof. Dr Borislav Guéorguiev (National Museum of Natural History, Bulgarian Academy of Sciences, Sofia, Bulgaria), Mr Max Barclay (Natural History Museum, London, UK) and an anonymous reviewer, whose constructive comments greatly improved the manuscript.

\section{References}

Anđelić M., Njunjić I., Jovanović J. \& Pavićević D. 2011. Rezultati interdisciplinarnih istraživanja Simine jame, selo Gornje Košlje, opština Ljubovija. In: Ćalić J. (ed.) Proceedings of the $7^{\text {th }}$ Symposium on Karst Protection (Bela Palanka, Serbia, 21-22.5.2011): 143-148. Student Speleologic and Alpinistic Club \& Municipality of Bela Palanka, Belgrade-Bela Palanka, Serbia.

Apfelbeck V. 1901. Drei neue Höhlenkäfer aus Bosnien. Verhandlungen der Kaiserlich-Königlichen Zoologisch-Botanischen Gesellschaft in Wien 51: 14-16.

Bosco F. 2016. 180 Grotte per Raccontare il Fenomeno Carsico in Serbia. Società di Studi Carsici “A.F. Lindner”, Ronchi dei Legionari, Italy.

Breit J. 1913. Wissenschaftliche Ergebnisse der Bearbeitung von O. Leonhard's Sammlungen. 5. Beiträge zur Blindkäferfauna von Bosnien und der Herzegowina. Entomologische Mitteilungen 2 (11): 351-358.

Culver D.C., Deharveng L., Bedos A., Lewis J.J., Madden M., Reddell J.R., Sket B., Trontelj P. \& White D. 2006. The mid-latitude biodiversity ridge in terrestrial cave fauna. Ecography 29: 120-128. https://doi.org/10.1111/j.2005.0906-7590.04435.x

Ćurčić S.B. 2005. Uporedno-morfološka svojstva, razviće i filogenija nekih zemljišnih i pećinskih tvrdokrilaca (Carabidae i Cholevidae = Leiodidae, Coleoptera) u Srbiji. $\mathrm{PhD}$ thesis, Faculty of Biology, University of Belgrade, Belgrade, Serbia.

Ćurčić S.B., Brajković M.M., Ćurčić B.P.M. \& Ćurčić N.B. 2006. A new cave-dwelling and endemic species of the genus Pholeuonopsis (Coleoptera, Leiodidae) from Serbia. Biologia, Bratislava 61 (5): 497-501. https://doi.org/10.2478/s11756-006-0082-0 
ĆURČIĆ S. et al., New leiodids (Coleoptera: Leiodidae) from western Serbia

Ćurčić S.B., Schönmann H., Brajković M.M. \& Ćurčić B.P.M. 2008a. Serboleonhardella gen. n., based on Proleonhardella remyi Jeannel (Leptodirini, Leiodidae, Coleoptera), from a cave in southwestern Serbia. In: Makarov S.E. \& Dimitrijević R.N. (eds) Advances in Arachnology and Developmental Biology. Papers Dedicated to Prof. Dr. Božidar Ćurčić: 463-473. Institute of Zoology, Faculty of Biology, University of Belgrade, Committee for Karst and Speleology, Serbian Academy of Sciences and Arts, Institute of Zoology, Bulgarian Academy of Sciences, Faculty of Life Sciences, University of Vienna \& UNESCO MAB Committee of Serbia, Vienna-Belgrade-Sofia, Austria-Serbia-Bulgaria.

Ćurčić S., Waitzbauer W., Zolda P., Brajković M.M. \& Ćurčić B.P.M. 2008b. New cave-dwelling species of the genus Remyella Jeannel (Leptodirini, Leiodidae, Coleoptera) from Serbia. Archives of Biological Sciences, Belgrade 60 (1): 109-115. https://doi.org/10.2298/ABS0801109C

Ćurčić S., Vrbica M., Vesović N., Antić D., Petković M., Bosco F. \& Ćurčić B. 2015. A new troglobitic species of the genus Pholeuonopsis (Coleoptera: Leiodidae: Cholevinae: Leptodirini) from western Serbia, with a key to the species from Serbia. Zootaxa 3937 (2): 393-400.

https://doi.org/10.11646/zootaxa.3937.2.10

Ćurčić S., Pavićević D., Vesović N., Mulaomerović J., Rađa T., Antić D., Bosco F., Marković Đ. \& Petković M. 2018. Seven new taxa of Leptodirini (Coleoptera: Leiodidae: Cholevinae) from the Balkan Peninsula. Zootaxa 4483 (3): 523-548. https://doi.org/10.11646/zootaxa.4483.3.6

Cvijić J. 1924. Geomorfologija I. Serbian Royal State Printing Office, Belgrade, Serbia.

Cvijić J. 1926. Geomorfologija II. Serbian Royal State Printing Office, Belgrade, Serbia.

Deharveng L., Gibert J. \& Culver D.C. 2012. Diversity patterns in Europe. In: White W.B. \& Culver D.C. (eds) Encyclopedia of Caves. Second Edition: 219-228. Academic Press, Amsterdam, the Netherlands.

Gaudenyi T. \& Jovanović M. 2012. Quaternary stratigraphy - recent changes. Bulletin of the Serbian Geographical Society 92 (4): 1-16. https://doi.org/10.2298/GSGD1204001G

Gibbard P.L., Head M.J., Walker M.J.C. \& the Subcommission on Quaternary Stratigraphy 2010. Formal ratification of the Quaternary System/Period and the Pleistocene Series/Epoch with a base at 2.58 Ma. Journal of Quaternary Science 25 (2): 96-102. https://doi.org/10.1002/jqs.1338

Guéorguiev V.B. 1976. Recherches sur la taxonomie, la classification et la phylogenie des Bathysciinae (Coleoptera Catopidae). Dissertationes Academiae Scientiarum et Artium Slovenicae, Ljubljana 19 (4): 91-147.

Hlaváč P., Perreau M. \& Čeplík D. 2017. The Subterranean Beetles of the Balkan Peninsula: Carabidae, Leiodidae, Staphylinidae, Scarabaeidae, Bothrideridae, Zopheridae, Salpingidae, Brachyceridae, Curculionidae. Faculty of Forestry and Wood Sciences, Czech University of Life Sciences Prague, Prague, Czech Republic.

Jeannel R. 1910. Essai d'une nouvelle classification des Silphides cavernicoles. Archives de Zoologie expérimentale et générale 45 (1): 1-48.

Jeannel R. 1911. Revision des Bathysciinae (Coléoptères Silphides): Morphologie, Distribution Géographique, Systématique. Libraire A. Schulz, Paris, France. https://doi.org/10.5962/bhl.title.63151

Jeannel R. 1924. Monographie des Bathysciinae. Biospeologica L. Archives de Zoologie expérimentale et générale 63: 1-436.

Jeannel R. 1930. Revision des genres Blattochaeta et Antroherpon (Bathysciinae). L'Abeille 34: 123148.

Jeannel R. 1931. Bathysciinae nouveaux recueillis par P. Rémy dans les grottes du Novi-Pazar. Bulletin de la Société zoologique de France 56: 258-266. 
Jeannel R. 1934. Bathysciinae recueillis par M. M. Rémy et R. Husson dans le Sandjak de Novi-Pazar et la Macédoine grecque. Revue française d'entomologie 1: 89-103.

Knirsch E. 1928. Coleoptera nova subterranea. Časopis Československé společnosti entomologické 25 (5-6): 81-98.

Kozel P., Delić T. \& Novak T. 2020. Nemaspela borkoae sp. nov. (Opiliones: Nemastomatidae), the second species of the genus from the Dinaric Karst. European Journal of Taxonomy 717: 90-107. https://doi.org/10.5852/ejt.2020.717.1103

Moldovan O.T., Kováč L. \& Halse S. (eds) 2018. Cave Ecology. Ecological Studies, Volume 235. Springer, Cham, Switzerland.

Njunjić I., Perreau M. \& Pavićević D. 2015. Two new species of the genus Anthroherpon Reitter, 1889 from northern Montenegro with notes on the "A. ganglbaueri" species group (Coleoptera: Leiodidae: Cholevinae: Leptodirini). Zootaxa 3915 (3): 403-412. https://doi.org/10.11646/zootaxa.3915.3.5

Njunjić I., Schilthuizen M., Pavićević D. \& Perreau M. 2017. Further clarifications to the systematics of the cave beetle genera Remyella and Rozajella (Coleoptera: Leiodidae: Cholevinae: Leptodirini). Arthropod Systematics \& Phylogeny 75 (1): 141-158.

Njunjić I., Perrard A., Hendriks K., Schilthuizen M., Perreau M., Merckx V., Baylac M. \& Deharveng L. 2018. Comprehensive evolutionary analysis of the Anthroherpon radiation (Coleoptera, Leiodidae, Leptodirini). PLoS ONE 13 (6): e0198367. https://doi.org/10.1371/journal.pone.0198367

Nonveiller G. 1983. Endogejska i troglobiontska fauna tvrdokrilaca Srbije (Insecta, Coleoptera). I. Istraživanja od 1976. do 1982. Zbornik radova o Fauni SR Srbije 2: 267-299.

Nonveiller G. \& Pavićević D. 1999. Tartariella durmitorensis n. gen. et n. sp., troisième Leptodirini de la chaîne Dinarique à mœurs hadésiennes (Coleoptera, Leiodidae). Bulletin de la Société entomologique de France 104 (4): 307-318.

Pavićević D., Popović M., Komnenov M. \& Njunjić I. 2012. Diversity of arthropod fauna in caves and pits of Kamena Gora (Serbia) and its surroundings. In: Pavićević D. \& Perreau M. (eds) Fauna Balkana. Volume 1: 151-176. Department of Biology and Ecology, Faculty of Sciences, University of Novi Sad, Novi Sad, Serbia.

Perreau M. 1999. Nouveaux genres et nouvelles espèces de Leptodirini (Coleoptera, Leiodidae). Bulletin de la Société entomologique de France 104 (4): 399-406.

Perreau M. 2000. Catalogue des Coléoptères Leiodidae Cholevinae et Platypsyllinae. Mémoires de la Société entomologique de France 4: 1-461.

Perreau M. 2015. Family Leiodidae Fleming, 1821. In: Löbl I. \& Löbl D. (eds) Catalogue of Palaearctic Coleoptera. Volume 2/1. Hydrophiloidea - Staphylinoidea. Revised and Updated Edition: 180-291. Brill, Leiden-Boston, the Netherlands-USA.

Perreau M. 2019. Phylogeny of Bathysciotina Guéorguiev, 1974, based on morphology with a special emphasis to Italian genera and with the description of a new species of Halbherria (Coleoptera Leiodidae Cholevinae Leptodirini). Zootaxa 4590 (3): 367-381. https://doi.org/10.11646/zootaxa.4590.3.3

Perreau M. \& Pavićević D. 2008. The genus Hadesia Müller, 1911 and the phylogeny of Anthroherponina (Coleoptera, Leiodidae, Cholevinae, Leptodirini). In: Pavićević D. \& Perreau M. (eds) Advances in the Studies of the Fauna of the Balkan Peninsula. Papers Dedicated to the Memory of Guido Nonveiller: 215-239. Institute for Nature Conservation of Serbia, Belgrade, Serbia.

Reitter E. 1910. Eine neue Bathyscia aus Dalmatien. Wiener entomologische Zeitung 29 (5-6): 164. https://www.biodiversitylibrary.org/page/12086245 
Reitter E. 1913. Sechs neue von Herrn Weirather in Bosnien entdeckte Höhlensilphiden. Koleopterologische Rundschau 10: 153-157.

Ribera I., Fresneda J., Bucur R., Izquierdo A., Vogler A.P., Salgado J.M. \& Cieslak A. 2010. Ancient origin of a western Mediterranean radiation of subterranean beetles. BMC Evolutionary Biology 10: 29. https://doi.org/10.1186/1471-2148-10-29

Sendra A. \& Reboleira A.S.P.S. 2020. Euro-Mediterranean fauna of Campodeinae (Campodeidae, Diplura). European Journal of Taxonomy 728: 1-130. https://doi.org/10.5852/ejt.2020.728.1181

Sket B. 2004. Dinaric karst: biospeleology. In: Gunn J. (ed.) Encyclopedia of Caves and Karst Science: 595-598. Taylor \& Francis, New York, USA.

Sket B. 2005. Dinaric karst, diversity. In: Culver D.C. \& White W.B. (eds) Encyclopedia of Caves: 158-165. Elsevier, Amsterdam, the Netherlands.

Zagmajster M., Culver D.C. \& Sket B. 2008. Species richness patterns of obligate subterranean beetles (Insecta: Coleoptera) in a global biodiversity hotspot - effect of scale and sampling intensity. Diversity and Distributions 14: 95-105. https://doi.org/10.1111/j.1472-4642.2007.00423.x

Zariquiey R. 1927. Nuevos Bathysciinae de los Balcanes (Col. Silphidae). Butlletí de l'Institució Catalana d'Història Natural 27: 152-158.

Manuscript received: 3 March 2021

Manuscript accepted: 13 October 2021

Published on: 1 December 2021

Topic editor: Nesrine Akkari

Section editor: Max Barclay

Desk editor: Pepe Fernández

Printed versions of all papers are also deposited in the libraries of the institutes that are members of the EJT consortium: Muséum national d'histoire naturelle, Paris, France; Meise Botanic Garden, Belgium; Royal Museum for Central Africa, Tervuren, Belgium; Royal Belgian Institute of Natural Sciences, Brussels, Belgium; Natural History Museum of Denmark, Copenhagen, Denmark; Naturalis Biodiversity Center, Leiden, the Netherlands; Museo Nacional de Ciencias Naturales-CSIC, Madrid, Spain; Real Jardín Botánico de Madrid CSIC, Spain; Zoological Research Museum Alexander Koenig, Bonn, Germany; National Museum, Prague, Czech Republic. 